\title{
Revision of the South American species of Neralsia (Hymenoptera: Figitidae) with the description of eight new species
}

\author{
M. Jiménez ${ }^{1}$, N.B. Díaz ${ }^{2}$, F. Gallardo ${ }^{2}$, P. Ros-Farré ${ }^{1}$ \& J. Pujade-Villar ${ }^{1}$ \\ 1 Universitat de Barcelona, Facultat de Biologia, Departament de Biologia Animal, Avda. Diagonal 646, 08028-Barcelona, \\ España. Fax (+34) 934035740; mauriziojimenez@yahoo.es; palmira.ros.farre@gmail.com; jpujade@ub.edu \\ 2 División Entomología, Museo de La Plata, Paseo del Bosque, 1900-La Plata, Argentina. Fax (54) 254232575; \\ ndiaz@museo.fcnym.unlp.edu.ar; gallardo@museo.fcnym.unlp.edu.ar
}

Received 12-III-2007. Corrected 11-X-2007. Accepted 20-XI-2007.

\begin{abstract}
Neralsia is a genus of Figitid hymenopterans present in both the Neartic and the Neotropical regions. In this work, material from several museums (including all types of the South American species of Neralsia) was analyzed with light and electron microscopy. The South American species are studied as a whole, reviewing 26 previously cited species and describing eight new species. A key for their identification is included and the characters to differentiate species here considered are illustrated. Rev. Biol. Trop. 56 (2): 795-828. Epub 2008 June 30 .
\end{abstract}

Key words: Cynipoidea, Figitidae, Figitinae, Neralsia, South America, revision, new species.

The genus Neralsia was described by Cameron (1883) to include a species collected in Guatemala, Neralsia rufipes, characterized, according to the author, by presenting the radial cell closed. Weld (1930), after studying this species type, affirmed that this cell was open; the study of this material allowed us to check Cameron's mistake and observe that the radial cell of $N$. rufipes presents a marginal darkening that should not be considered as a real venation. Weld (1930) established the synonymy between Neralsia and Xyalosema, and transferred the species of the latter genus to Neralsia, except for Xyalosema singularis (Ashmead 1896) that was transferred to Xyalophora Kieffer 1901. Afterwards, Weld (1952) transferred all the American species of Xyalophora to the genus Neralsia. Neralsia and Xyalophora gather the figitines presenting the distal part of the scutellum in the form of a spine, differently to the rest where the scutellum is distally blunt.

Species included in this subfamily are characterized by being parasitoids of Diptera-Muscomorpha; these cause huge economical losses in crops of multiple areas and especially in the Neotropical region (Clavijo 1993, Madrigal-Cardeño 2001, among others). The only bio-economical known datum for the species of Neralsia was the observation made by Díaz (1990) for Neralsia fossulata (=splendens), the representatives of this species attack pre-imaginal states of Diptera of dung of the genus Sarcophagula (Sarcophagidae); later studies (Díaz and Gallardo 1995, 1996, Díaz et al. 2000, Marchiori et al. 2000a-e, 2003) have corroborated the presence of $N$. fossulata in Sarcophagula occidua in several countries of South America. Recently, it was described a new species in North America (Jiménez et al., in prep.) that parasitoidizes larvae of Sarcophaga bullata.

Figitines and particularly those from the genus Neralsia are distributed along the whole American continent and are especially abundant in South America. This one is the fifth 
contribution made by the authors aiming to update the knowledge of the named taxon in this part of the continent. Till today, the morphological characters to take into account in the identification of the species have been analyzed, considering as a reference Dettmer's survey (1932) (Jiménez et al. 2005a); the types of the described species in South America were studied (Jiménez et al. 2004), and 17 new species were described (Jiménez et al. 2005b, 2006a).

\section{MATERIALS AND METHODS}

Part of the material analyzed belongs to samples conserved in $70^{\circ}$ (Canadian National Collection of Insects, Ottawa, Canada) and that collected in campaigns made in several South American countries (Argentina, Bolivia, Brazil and Colombia). These samples were conveniently dried, glued to entomological cards with Arabic glue and labelled, following the standard procedure for entomological studies. All types of the South American species of Neralsia (Jiménez et al. 2004, 2005b, 2006a, Pujade-Villar et al. 2006) were analyzed; the type species of Xyalophora, Figites clavatus Giraud 1860 (Muséum National d'Histoire Naturelle, Paris, France), the Neralsia, N. rufipes Cameron 1883 (British Museum, London, United Kingdom), and the type species of Solenaspis transferred afterwards to Xyalosema (because of homonymy), S. hyalinipennis Ashmead 1887 (Smithsonian Institution National Museum of Natural History, Washington DC, USA) were analyzed.

The acronyms of the institutions where the rest of the material examined is conserved and the name of the people responsible of the collections are listed below:

AMNH (American Museum of Natural History, New York, NY, USA; D. Grimaldi)

CNCI (Canadian National Collection of Insects, Ottawa, Canada; G. Gibson)
CAS (California Academy of Sciences, San Francisco, California, USA; R. Zuparko)

DCBU (Departamento de Biología de la Universidad Federal de Sao Carlos, SP, Brazil; A. Penteado-Días)

FOC (Fundación Oswaldo Cruz, Rio de Janeiro, Brazil; S.J. da Oliveira)

LACM (Los Angeles County Museum of Natural History, Los Angeles, California, USA; B.V. Brown)

MEL (Museo Entomológico de León, León, Nicaragua; J.M. Maes)

MLP (Museo de La Plata, La Plata, Argentina; N.B. Díaz)

MNHN-Paris (Muséum National d'Histoire Naturelle, Paris, France; C. Villeman)

MNHN-Chile (Museo Nacional de Historia Natural de Chile, Santiago, Chile; F. Rojas A.)

MNRJ (Museo Nacional de Rio de Janeiro, Brazil; M. Monné)

MZUSP (Museu de Zoologia da Universidade de São Paulo, Brazil; C.R.F. Brandao)

NHN (British Museum, London, United Kingdom; S. Lewis)

NMM (Naturhistorisch Museum Maastricht, Netherlands; F. Dingemans-Bakels)

UB (Universitat de Barcelona, Barcelona, Spain; J. Pujade-Villar).

UCR (Universidad de Costa Rica, San Pedro, Costa Rica; P. Hanson)

UFES (Universidade Federal do Espíritu Santo, Brazil; C.O. Acevedo) 
USNM (United States National Museum of Natural History, Smithsonian Institution, Washington DC, USA; D. Furth)

ZMB (Zoologisches Museum HumboldtUniversität, Berlin, Germany; R. Koch)

The data detailed for each of the studied specimens are a faithful copy of the existing labels.

Pictures illustrating this survey were taken with scanning electron microscope (Stereoscan Leica 360) in the Servicio Científico-Técnico of the Universidad de Barcelona, at low voltage and without gold cover to preserve the specimens. Pictures of the radial cells were obtained with a digital camera (Minolta model Dimage-Xt) and were taken directly through the ocular of a lens (Olympus model SZ30). Drawings of the antennae were made by hand from the digital pictures directly obtained from binocular lens.

For the terminology of the morphological structures were considered works made by Gibson (1985) and Ronquist and Nordlander (1989), and to define the sculpture the one by Harris (1979). Measures and abbreviations used include: F1-F11, first and subsequent flagellomeres; POC (post-ocellar distance) is the distance between the internal margins of the posterior ocellus; OOC (ocellus-ocular distance) is the distance between the external margin of the lateral ocellus and the internal margin of the compound eye; COC (ocellar distance) is the distance between the lateral and frontal ocellus; the diameter of the lateral ocellus is the biggest one of this organ; the transfacial line is the distance between the internal margin of the compound eyes measures at the antennal foveae. For the adults length, the maximum and minimum value of the individuals studied is indicated.

In the description of new species, in the case that specimens of both sexes have been able to be studied, the characters are common to both, unless the contrary is indicated; characters showing sexual dimorphism are not included in this generalization, such as: sculpturation of the face, antennae and the aspect of the metasoma, in which case the female is described; males, for these features, do not show specific differentiation, they are homogenous within the genus.

\section{RESULTS}

\section{Species treatment}

\author{
Neralsia albipennis \\ (Kieffer 1909) (Fig. 1A, B)
}

Xyalophora albipennis Kieffer 1909: 94

Neralsia albipennis (Kieffer 1909) Jiménez et al. 2004: 64

Studied material: see Jiménez et al. 2004. Additional material studied. ARGENTINA: Bariloche, Río Negro, Arg., Nov. 1929, R. \& E. Shannon: 1 male (USNM); Bariloche, Rio Negro, Arg., XI. 1926, R. \& E., Shannon: 1 male (USNM) CHILE: Rivadavia, Chile, Coquimbo, 30.X.1957, L.E. Peña: 1 male (CNCI); El Manzano, Cord. Ovalle, XI.1964, Peña: 1 female (CNCI); Santiago, Renca, 26.II.1965, Col. T. Ramírez, S., Neralsia: 1 male (MNHNChile).

Diagnosis: re-described in Jiménez et al. 2004: 64. Neralsia albipennis, belongs to the group of species with low interfoveal carina; in this case the aforementioned carina is at the same level as the scutellar foveae. It is differentiated from the rest of South American species that also present this feature by being the only one with the scutellar disc hunchbacked (Fig. 1A).

Distribution: known species from Argentina, Bolivia, Brazil and Chile (Jiménez et al. 2004).

Neralsia pseudoneralsia

Jiménez and Pujade-Villar 2006

(Fig. 1C, D)

Neralsia pseudoneralsia Jiménez and PujadeVillar 2006a: 63. 

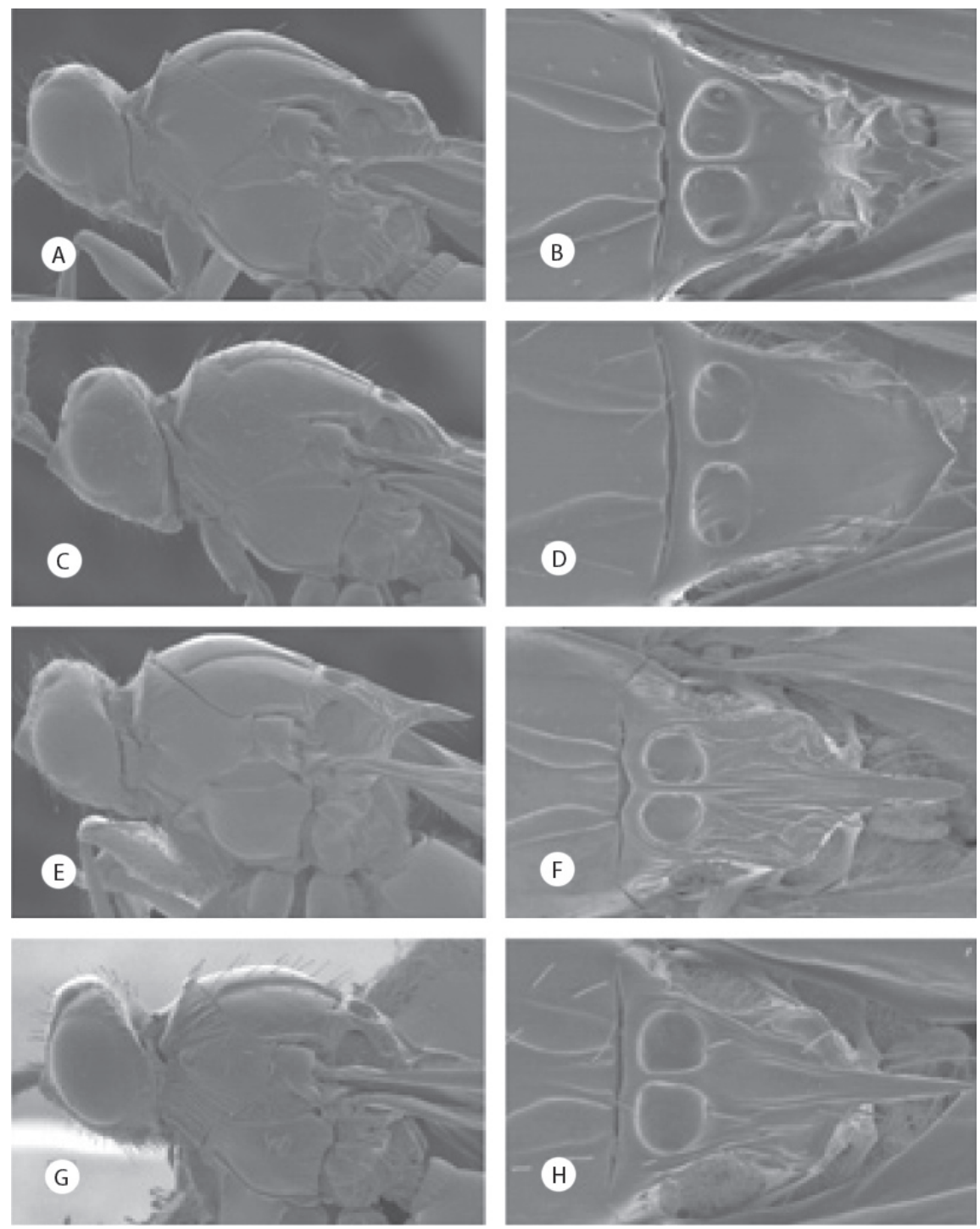

Fig. 1. Cabeza y mesosoma (A, C, E, G) en vista lateral; detalle del escutelo (B, D, F, H) en vista dorsal: Neralsia albipennis (A, B), N. pseudoneralsia (C, D), N. pilosa (E, F) y N. incompleta (G, H).

Fig. 1. Head and mesosoma (A, C, E, G) in lateral view; detail of scutellum (B, D, F, H) in dorsal view : Neralsia albipennis (A, B), N. pseudoneralsia (C, D), N. pilosa (E, F) y N. incompleta (G, H). 
Studied material: see Jiménez et al. 2006a. Additional material studied. ARGENTINA: Horco Molle, Tucumán, Argentina, VI. 1968, C.C. Porter: 1 female (CNCI); VENEZUELA: Kavanayen, Gran Sabana, 28. XIII. 1987, M. Sanborne, Mal.-intercept tp. (forest); Xyalophora, det. K. Schick, 2003: 1 female (CNCI).

Diagnosis: Neralsia pseudoneralsia belongs to the group of species with low interfoveal carina. It is differentiated from the rest of South American species by this feature, by presenting the scutellar disc smooth and flat, and the spine extremely short (Fig. 1D). The closest species are $N$. equilatera and $N$. moisesi with which share the characteristics of the flagellomeres and the metasomal tergum II and from which is easily separated by presenting wings with marginal setae.

Distribution: species known from Argentina (Jiménez et al. 2006a). In this study it is also cited from Venezuela.

Neralsia pilosa

(Borgmeier 1935) (Fig. 1E, F)

Xyalophora pilosa Borgmeier 1935: 103

Neralsia pilosa (Borgmeier 1935) Weld 1952: 176

Studied material: see Jiménez et al. 2004.

Diagnosis: re-described in Jiménez et al. 2004: 76. Neralsia pilosa belongs to the group of species with low interfoveal carina. It is the only described species of Neralsia that presents dense long pubescence, whitish and silky in the face and the legs, and that lacks genal sulcus.

Distribution: species only known from Brazil (Jiménez et al. 2004). It has not been found again since its description.

\section{Neralsia incompleta}

Jiménez and Pujade-Villar 2006

(Fig. 1G, H, 10H)

Neralsia incompleta Jiménez and Pujade-Villar 2006b: 47
Studied material: see Pujade-Villar et al. 2006b.

Diagnosis: Neralsia incompleta belongs to the group of species with low interfoveal carina and metasomal tergum II completely smooth at base. It is differentiated from the rest of known South American species by presenting the radial cell incomplete, R1 is very short, being located very far from the wing margin (Fig. $10 \mathrm{H}$ ) or absent.

Distribution: species widely distributed in the whole American continent; in South America it has been collected only from Paraguay (Pujade-Villar et al. 2006b).

Neralsia equilatera

Jiménez and Pujade-Villar 2006

(Fig. 2A, B)

Neralsia equilatera Jiménez and Pujade-Villar 2006a: 60

Studied material: see Jiménez et al. 2006a.

Diagnosis: Neralsia equilatera belongs to the group of species with low interfoveal carina. Together with $N$. moisesi is included in the subgroup of those that present the anterior wings with no marginal setae and are differentiated between them by the character indicated in the key. From N. pseudoneralsia (Fig. 1D), that also has the scutellar spine very short, it is differentiated by presenting the scutellum disc carinated (Fig. 2B).

Distribution: species known from Argentina and Chile (Jiménez et al. 2006a).

Neralsia moisesi

Jiménez and Pujade-Villar 2006 (Fig. 2C, D)

Neralsia moisesi Jiménez and Pujade-Villar 2006a: 61

Studied material: see Jiménez et al. 2006a.

Diagnosis: Neralsia moisesi belongs to the group of species with low interfoveal carina 

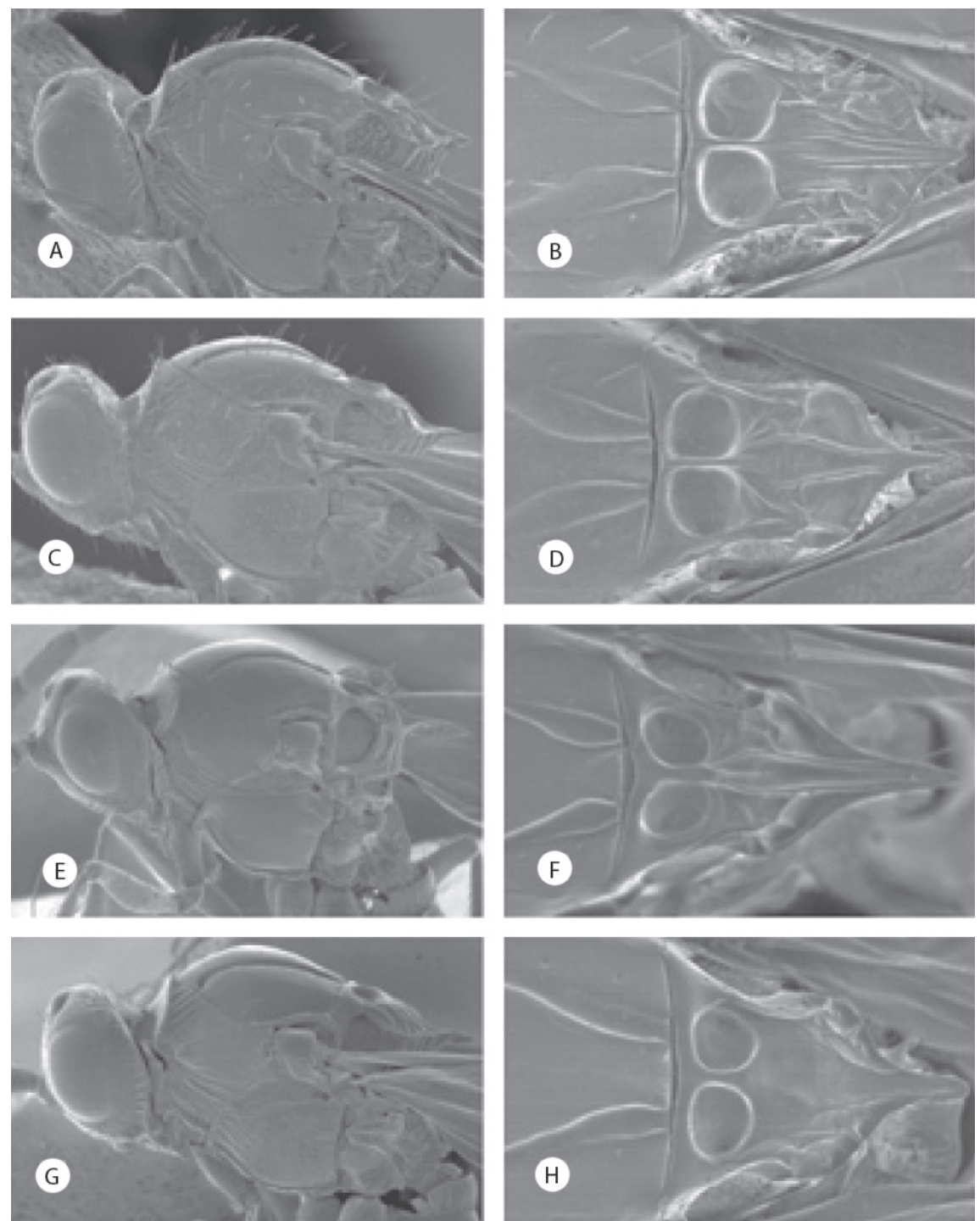

Fig. 2. Cabeza y mesosoma (A, C, E, G) en vista lateral; detalle del escutelo (B, D, F, H) en vista dorsal: Neralsia equilatera (A, B), N. moisesi (C, D), N. preta n. sp. (E, F) y N. difilippoi n. sp (G, H).

Fig. 2. Head and mesosoma (A, C, E, G) in lateral view; detail of scutellum (B, D, F, H) in dorsal view: Neralsia equilatera (A, B), N. moisesi (C, D), N. preta n. sp. (E, F) y $N$. difilippoi n. sp (G, H). 
and metasomal tergum II smooth at base. It is similar to $N$. equilatera, $N$. pseudoneralsia, and $N$. desantisi, because of the form of the flagellomeres; from these it is easily differentiated by the characteristics of the scutellum; $N$. moisesi (Fig. 2D) presents the scutellar spine shorter than $N$. desantisi (Fig. $4 \mathrm{H}$ ) and more developed than $N$. equilatera (Fig. 2B) and $N$. pseudoneralsia (Fig. 1D). From the latter (Fig. 1D), it is distinguished, moreover, by presenting the scutellar disc carinated (Fig. 2D).

Distribution: species known from Argentina, Chile and Venezuela (Jiménez et al. 2006a).

\section{Neralsia preta}

Jiménez and Pujade-Villar n. sp (Fig. 2E, F, 10k)

Etymology: the name of the species alludes to the dark pigmentation of the specimen studied; only the ventral part of the metasoma is reddish.

Type material: holotype (male) deposited in CNCI (Ottawa, Canada), BOLIVIA: "Yungas, Chaparé, 2200 m, 1-4.II.1976, L.E. Pena" (white label), Holotype desig.-2004 Jiménez and Pujade-Villar" (red label), "Neralsia preta n. sp male Jiménez and Pujade-Villar det.2004" (white label).

Diagnosis: Neralsia preta $n$. sp. is differentiated from the rest of described species of the genus by its coloration and the presence of a genal sulcus completely smooth.

Length: male: $4.3 \mathrm{~mm}$; female: unknown.

Coloration: black (body, antennae and legs), but for the ventral part of the metasoma which is dark reddish. Wings slightly dusky, venation brown.

Head: in frontal view sub-squared, in dorsal view 1.8 times longer than wide. Face with two smooth areas. Transfacial line 1.2 times longer than the height of the eye. The relation POL:OOL:OCO is $7: 6: 3.5$, diameter of the lateral ocellus 4.5 . Genal sulcus hardly marked and completely smooth. Occiput carinated.

Antennae: F1 shorter than the rest of the flagellomeres (as in all males of Neralsia species studied).
Mesosoma (Fig. 2E, F): pronotal plate incised. Lateral areas of the pronotum smooth, with scarce carinae weakly marked in the dorsal part and in greater number than in the ventral part. Mesopleura smooth in most of it surface, presenting antero-ventral striae. Medial sulcus of the scutum very marked. Interfoveal carina surpassing slightly the level of the scutellar foveae. Scutellar disc strongly carinated, being noticed two carinae that begin in the interfoveal carina and end in the base of the spine, forming between them a wide and smooth sulcus, the rest of the disc with short longitudinal carinae that do not reach the posterior margin. Scutellar spine wide in the base, bigger than $1 / 3$ the total length of the scutellum.

Metasoma: tergum I carinated. Tergum II with scarce short striate at base.

Distribution: species collected from Bolivia.

\section{Neralsia difilippoi \\ Jiménez and Pujade-Villar n. sp. \\ (Fig. 2G, H, 10D)}

Etymology: species dedicated, in posthumous memory, to the Italian ancestor of one of the authors, his grandmother in his mother's side Aurora Difilippo Pianetta (1916-1977).

Type material: holotype (male) deposited in CNCI (Ottawa, Canada), ECUADOR: C-386“1900 Laja, Malacutos, 21-27.VIII.1977” (white label), Holotype desig.-2004 Jiménez and Pujade-Villar" (red label), "Neralsia difilippoi n. sp male Jiménez and Pujade-Villar det. 2004" (white label).

Diagnosis: Neralsia difilippoi $\mathrm{n}$. sp. presents a scutellum very particular that makes this species unmistakable with any other species of this genus. The surface of the disc of the scutellum is almost smooth, with no medial carina, central sulcus absent; these characters set it close N. pseudoneralsia from which is distinguished by the length of the spine (Fig. 1D). On the other hand, $N$. difilippoi $n$. sp. presents the scutellar spine blunt and of the same thickness in all its way (Fig. $2 \mathrm{H}$ ), characters that set it close to $N$. flavidipennis and $N$. hermaphrodita, 
in which the scutellar spine is far longer (Fig. 3B, D).

Length: male: $2.6 \mathrm{~mm}$; female: unknown.

Coloration: black, except for the antennae and tegulae that are reddish brown. Translucent wings, venation pale brown.

Head: in frontal view sub-triangular, in dorsal view 1.9 times longer than wide. Transfacial line 0.94 times as long as the height of the eye. The relation POL:OOL:OCO is $8: 6.5: 4$, diameter of the lateral ocellus 3.5. Genal sulcus present, provided with some transversal costulae.

Antennae: F1 hardly shorter F2, the rest of the flagellomeres three times longer than wide, all with sensilia.

Mesosoma (Fig. 2G, H): Lateral areas of the pronotum with scarce sharp carinae and very visible in the anterior dorsal part, more abundant in the ventral part, the posterior smooth. Mesopleura smooth in most of its surface, with striae only in the anterior ventral part. Medial sulcus of the scutellum very marked. Interfoveal carina slightly surpassing the level of scutellar foveae. Scutellar disc smooth, scutellar sulcus hardly defined, spine of uniform thickness, finished bluntly, its size $1 / 3$ of the total length of the scutellum.

Wings: radial cell 2.3 times longer than wide (Fig. 10D). Discal and marginal setae present. Areolet incomplete.

Metasoma: tergum I wide, strongly carinated. Tergum II completely smooth at base.

Distribution: species collected from Ecuador.

Neralsia flavidipennis

(Kieffer 1909) (Fig. 3A, B, 11G)

Xyalophora flavidipennis Kieffer 1909: 95

Neralsia flavidipennis (Kieffer 1909) Weld 1952: 176

Studied material: see Jiménez et al. 2004.

Diagnosis: re-described in Jiménez et al. 2004: 71. Neralsia flavidipennis belongs to the group of species with low interfoveal carina and metasomal tergum II with scarce striae at base. The closest species are $N$. difilippoi n. sp. and $N$. hermaphrodita. From $N$. difilippoi n. sp., it is differentiated by the morphology of the scutellum and from $N$. hermaphrodita by the characters indicated in the key.

Distribution: species known from Argentina, Bolivia, Ecuador and Peru (Jiménez et al. 2004).

\author{
Neralsia hermaphrodita \\ Jiménez and Pujade-Villar 2006 \\ (Fig. 3C, D, 10G, 11H)
}

Neralsia hermaphrodita Jiménez and PujadeVillar 2006a: 63.

Material studied: see Jiménez et al. 2006a.

Diagnosis: Neralsia hermaphrodita belongs to the group of species with low interfoveal carina. It is similar to $N$. pilosa given the pubescence of the mesosoma, and to $N$. flavidipennis given the morphology of the scutellar spine. Females of $N$. hermaphrodita (males unknown) are easily separated from the other known species of this group when considering the form of the flagellomeres (with similar aspect to males of Neralsia). This feature is also present in N. ellongata, species of the group with high interfoveal carina.

Distribution: species only known from Brazil (Jiménez et al. 2006a).

Observations: when describing $N$. hermaphrodita in Jiménez et al. (2006a: 63) it is erroneously said that the radial cell is closed, when it is actually open in the frontal margin, this structure presents a darkening that should not be considered as a vein (Fig. 10G).

Neralsia fossulata

(Kieffer 1909) (Fig. 3E, F, 11K)

Xyalosema fossulata Kieffer 1909: 81

Neralsia fossulata (Kieffer 1909) Weld 1952: 176

Xyalophora splendens Borgmeier 1935: 102

Neralsia splendens (Borgmeier 1935) Weld 1952: 176; synonymyzed in Jiménez et al. 2004: 73. 

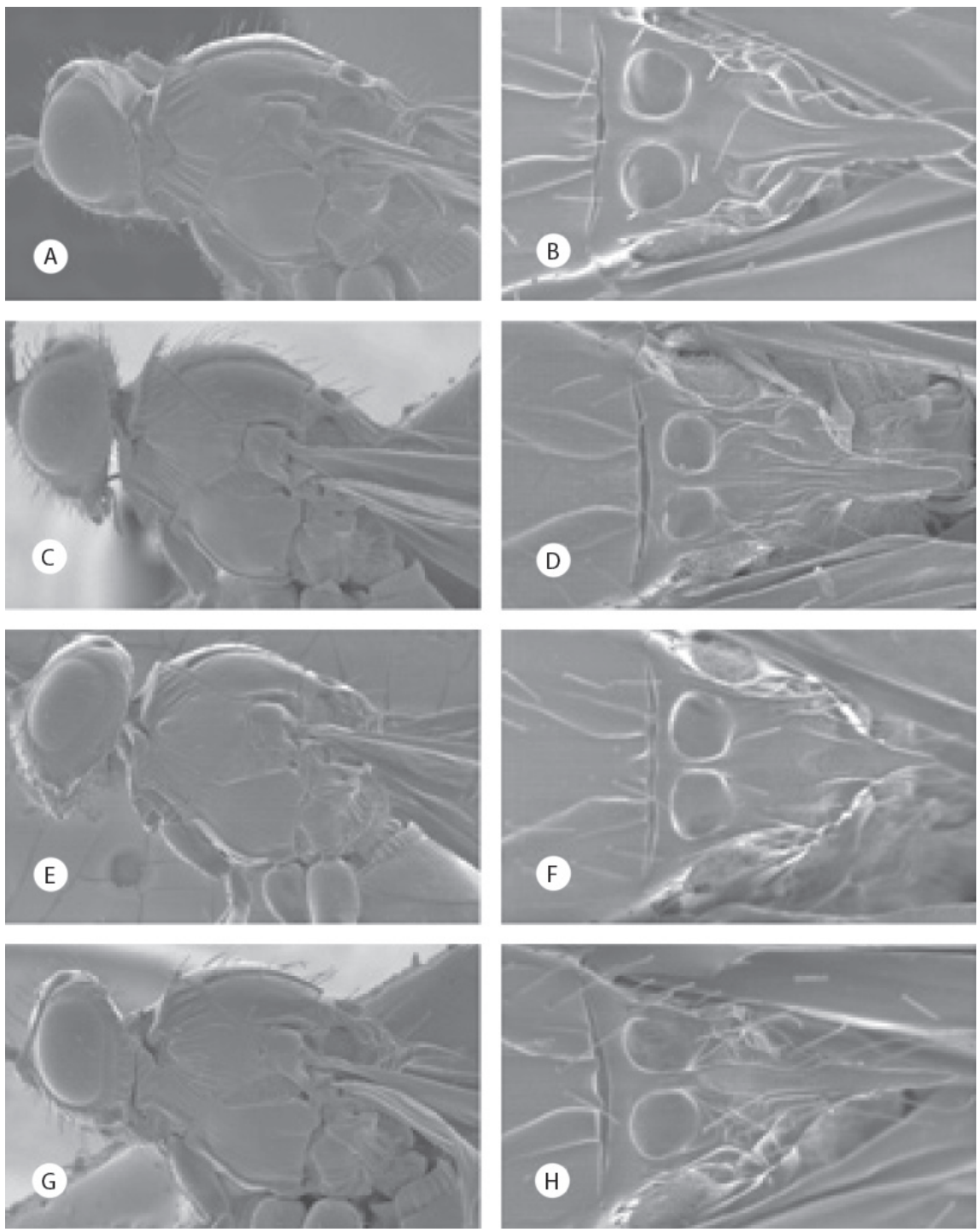

Fig. 3. Cabeza y mesosoma (A, C, E, G) en vista lateral; detalle del escutelo (B, D, F, H) en vista dorsal: Neralsia flavidipennis (A, B), N. hermaphrodita (C, D), N. fossulata (E, F) y N. striaticeps $(\mathrm{G}, \mathrm{H})$.

Fig. 3. Head and mesosoma (A, C, E, G) in lateral view; detail of scutellum (B, D, F, H) in dorsal view: Neralsia flavidipennis (A, B), N. hermaphrodita (C, D), N. fossulata (E, F) y N. striaticeps (G, H). 


\section{4.}

Studied material: see Jiménez et al.

Diagnosis: re-described in Jiménez et al. 2004: 73. Neralsia fossulata belongs to the group of species with low interfoveal carina and the metasomal tergum II densely striated at base. It stands out for having testaceous antennae (Fig. 11k), with short and moniliform flagellomeres, length of the pedicellum subequal to that of F2. On the other hand, it is the species with the smallest representatives of the genus (1.9-2.2 mm).

Distribution: species known from Argentina, Brazil and Peru (Jiménez et al. 2004).

Neralsia striaticeps

(Kieffer 1909) (Fig. 3G, H, 11J)

Xyalophora flavidipennis var. striaticeps Kieffer 1909: 95.

Xyalophora striaticeps Kieffer 1909, in Dettmer 1932: 124, 133.

Neralsia striaticeps (Kieffer 1909) Weld 1952: 176.

Studied material: see Jiménez et al. 2004. Additional material studied. BRAZIL: Luís Antonio, SP, Bra., 22.X.1987, L.A. Joaquin col.: 1 female (Angélica); Luis Antonio, S.P. Brazil, 12.III. 1987, L.A. Joaquim col: 1 female (Angélica); ECUADOR: C-368, Ecuador 1 female (CNCI); C-381, Ecuador, Napo, 400 m, Jatun Sacha Biol. Station $(21 \mathrm{Km}$ E, Puerto Napo), 9.VII.1994, F. Géner, virgen rain forest, feces tp: 1 female (CNCI); C-396 Napo. Oyacachi, $3150 \mathrm{~m}, 0^{\circ} 22^{\prime} \mathrm{S}, 78.08^{\circ} \mathrm{W}, 30 . \mathrm{II}-15$. IV.1996, Durero Ecuador (Oriente), 23-28. IX.1997 150-200 m: 1 male (CNCI); Ecuador, Pich., 47 Km S. Sto. Domingo, Rio Palenque Sta. 22-31.VI.1976, S. \& J. Peck: 1 female (CNCI); ARGENTINA: Loreto, Exp. St., Misiones, Arg., Dr. A.A. Ogloblin, 1 male and 2 females (MLP); Loreto, Misiones, 1930: 1 female (MLP); Exp. St. Loreto, Misiones, Arg., Dr. A.A. Ogloblin, 17.III.1932: 1 male.

Diagnosis: re-described in Jiménez et al. 2004: 77. Neralsia striaticeps, belongs to the group species with low interfoveal carina and metasomal tergum II densely striated at base. The closest species are $N$. fossulata, N. bogotensis, $N$. parafossulata and $N$. julianae n. sp. Differently to the mentioned species, $N$. striaticeps stands out by having a dense and abundant striation in the lateral areas of the pronotum and in the mesopleura (Fig. 3g).

Distribution: species of wide distribution in South America, known from Bolivia, Brazil, Colombia, Ecuador, French Guiana, Peru and Venezuela (Jiménez et al. 2004). In this survey it is also cited from Argentina.

\section{Neralsia bogotensis}

(Kieffer 1909) (Fig. 4A, B, 11I)

Xyalophora bogotensis Kieffer 1909: 95

Neralsia bogotensis (Kieffer 1909) Weld 1952: 176

Studied material: see Jiménez et al. 2004; Additional material studied. PERU: Pasco, Peru, 1 600-1 $800 \mathrm{~m}$., $10^{\circ} 35^{\prime} \mathrm{S}$; 75³5' W., 30-31.XII.1972., J. Helava: 1 male (CNCI); VENEZUELA: Venezuela, Mérida-Sta Rosa, cca. 1800 m., L. Master, 11.V.1981, Old cofee plant: 1 female (CNCI).

Diagnosis: re-described in Jiménez et al. 2004: 66. Neralsia bogotensis, belongs to the group of species with low interfoveal carina and metasomal tergum II densely striated at base. The closest species is $N$. striaticeps from which is differentiated by the characteristics of the pronotum and the coloration of antennae.

Distribution: known species from Brazil, Colombia, Ecuador, Paraguay, Peru and Venezuela (Jiménez et al. 2004).

Neralsia parafossulata

Jiménez and Pujade-Villar 2006

(Fig. 4C, D, 10O, 111)

Neralsia parafossulata Jiménez and PujadeVillar 2006a: 68.

Studied material: see Jiménez et al. $2006 \mathrm{a}$ 

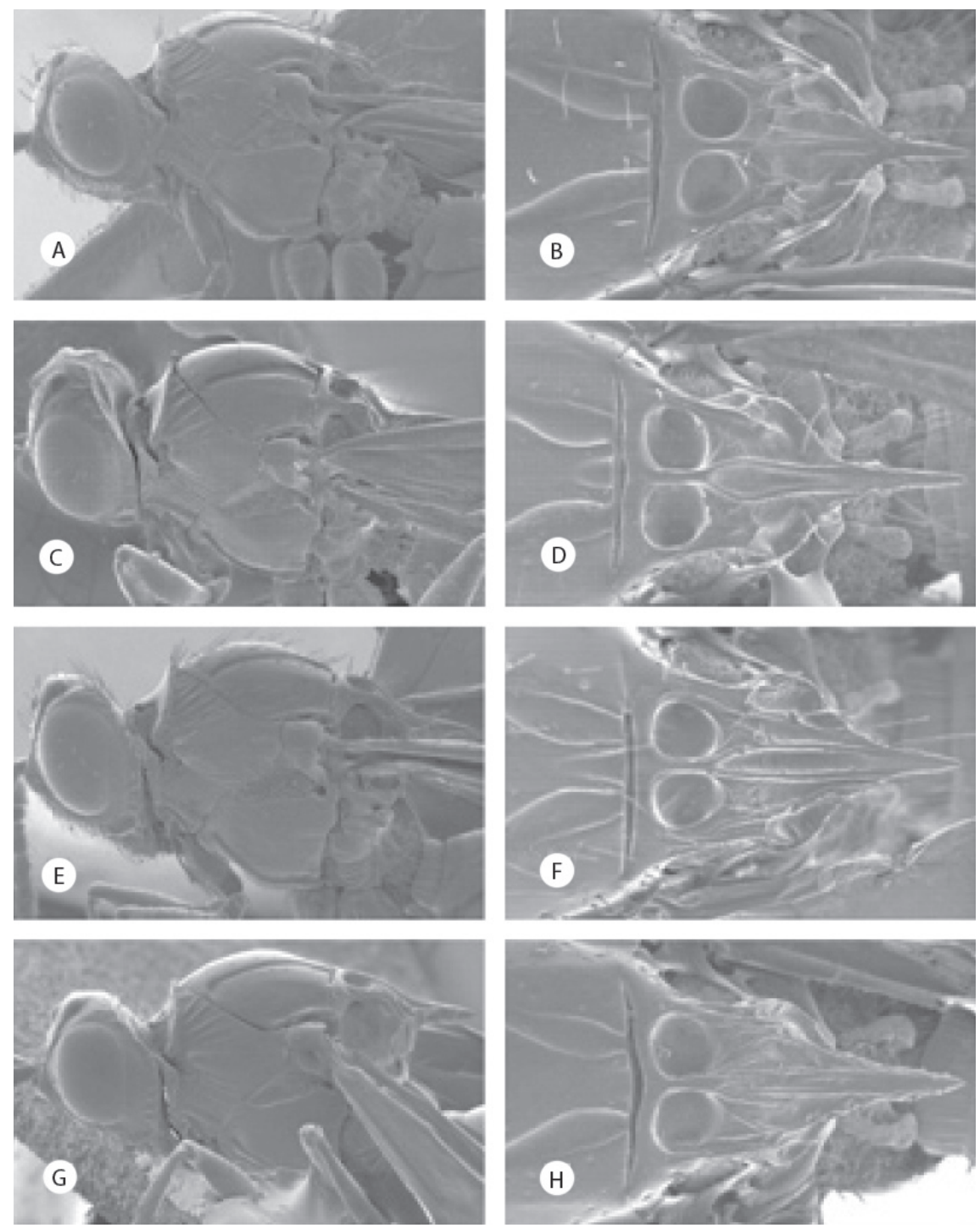

Fig. 4. Cabeza y mesosoma (A, C, E, G) en vista lateral; detalle del escutelo (B, D, F, H) en vista dorsal: Neralsia bogotensis (A, B), N. parafossulata (C, D), N. julianae n. sp. (E, F) y N. desantisi (G, H).

Fig. 4. Head and mesosoma (A, C, E, G) in lateral view; detail of scutellum (B, D, F, H) in dorsal view: Neralsia bogotensis (A, B), N. parafossulata (C, D), N. julianae n. sp. (E, F) y N. desantisi (G, H). 
Diagnosis: Neralsia parafossulata belongs to the group of species with low interfoveal carina and the base of the metasomal tergum II dense and uniformly striated. It is close to $N$. fossulata, $N$. bogotensis, $N$. striaticeps and $N$. julianae n. sp. Neralsia parafossulata is separated from the first three by its scarce mesopleural sculpturation and by the design of the striation in the face. The differences between $N$. parafossulata $\mathrm{n}$. sp. and $N$. julianae n. $\mathrm{sp}$. are indicated in the key.

Distribution: species known from Colombia and Venezuela (Jiménez et al. 2006a).

\section{Neralsia julianae \\ Jiménez and Pujade-Villar n.sp.}

(Fig. 4E, F, 10I, 11D)

Etymology: species dedicated to Juliana Salazar Rojas, friend of the first of the authors.

Type material: holotype (female) deposited in CNCI (Ottawa, Canada) BRAZIL: Nova Teutonia, $27^{\circ} 11^{\prime} \mathrm{S}, 52^{\circ} 23^{\prime} \mathrm{W}$, Brazil 300-500 m, VIII.1971, Fritz Plaumann: (white label), "Holotype desig. 2005, Jiménez and PujadeVillar" (red label); "Neralsia julianae n. sp. female Jiménez and Pujade-Villar det. 2005" (white label). Paratype: with the same data as the holotype: 1 male (CNCI).

Diagnosis: Neralsia julianae n. sp. belongs to the group of species with low interfoveal carina and low metasomal tergum II striated at base, together $N$. fossulata, N. striaticeps, $N$. bogotensis and $N$. parafossulata. The scarce sculpture of the mesopleura (Fig. 4E), the straight dorsal margin of the metasomal tergum VIII (Fig. 12I) and the sub-squared form of the last flagellomeres (Fig. 11D) allow differentiating it from the three first cited species for this group. The differences between $N$. julianae n. sp. and $N$. parafossulata are indicated in the key.

Length: female: $4.1 \mathrm{~mm}$; male: $3.0 \mathrm{~mm}$

Coloration: black. Antennae reddish brown; tegulae, legs and ventral area of the metasoma reddish. Translucent wings, venation brown.

Head: in frontal view sub-squared, in dorsal view twice longer than wide. Face of the female with striae that depart radially from the clipeus and the middle of the face towards the interfoveal antennae and the inferior part of the compound eyes, surface between them, smooth. Transfacial line equal in length to the height of the compound eye. The relation POL:OOL:OCO is 9:6:5; diameter of the lateral ocellus 5. Genal sulcus present, with transversal costulae marked. Occiput dorsally carinated; visible genal carina behind the compound eyes.

Antennae (Fig. 11D): F1 and F2 subequal in length, shorter than F3, last flagellomeres sub-squared, 1.1 times longer than wide. Sensilia absent in F1 and F2.

Mesosoma (Fig. 4E, F): Pronotal plate dorsally incised, lateral areas of the pronotum with scarce sharp and spaced carina in the dorsal part, thin and denser in anterior ventral part, the rest smooth. Mesopleura smooth in the greatest part of its surface, ventral part thinly striated. Medial sulcus of scutellum very marked and elongated. Low interfoveal carina, slightly surpassing the level of the scutellar foveae (lateral view). Scutellar disc very slightly carinated, being noticeable two carinae that form between them a smooth and well defined sulcus that reaches the middle of the spine. Scutellar spine long, bigger than $1 / 3$ of the total length of the scutellum.

Wings: radial cell 1.6 times longer than wide (Fig. 10I). Discal and marginal setae present. Areolet almost formed.

Metasoma: tergum I wide, strongly carinated. Tergum II uniformly striated at base. Dorsal margin of tergum VIII, in lateral view, straight.

Distribution: species collected from Brazil.

\section{Neralsia desantisi \\ Jiménez and Pujade-Villar 2006}

(Fig. 4G, H, 11M)

Neralsia desantisi Jiménez and Pujade-Villar 2006a: 65 . 
Studied material: see Jiménez et al. 2006a. Additional material studied. BRAZIL: Parasoles de Roma, Diadora, X.1937: 1 male (MNRJ).

Diagnosis: Neralsia desantisi belongs to the group of species with low interfoveal carina and the metasomal tergum smooth or with scarce striae at base, characters that share with $N$. cressoni n. sp., $N$. rauli and $N$. marioi. Neralsia desantisi presents the last flagellomeres sub-squared (Fig. $11 \mathrm{M}$ ), fact that differentiates it from the species previously cited whose flagellomeres are much longer than wide. The morphology of the antennal flagellomeres sets $N$. desantisi close to $N$. equilatera and $N$. moisesi, that also coincide in presenting the base of the metasomal tergum II smooth; nevertheless, $N$. equilatera and $N$. moisesi are differentiated from $N$. desantisi by lacking discal and marginal setae in the first pair of wings. The differences between $N$. desantisi and $N$. cressoni $\mathrm{n}$. sp. are indicated in the key.

Distribution: known species from Argentina (Jiménez et al. 2006a). In this survey it is also cited from Brazil.

\section{Neralsia cressoni \\ Jiménez and Pujade-Villar n. sp. \\ (Fig. 5A, B, 10B, 11B)}

Etymology: species dedicated to the United States hymenopterologist Ezra Townsend Cresson (1838-1926).

Type material: holotype (female) deposited in CNCI (Ottawa, Canada) VENEZUELA: "Mérida, Tabay La Mucuy, 1900 m, 18.VII-2. VIII.1989, S. \& J. Peck, MT., Streamside meadow" (white label), "Holotype desig. 2004, Jiménez and Pujade-Villar" (red label), Neralsia cressoni n. sp. female Jiménez and Pujade-Villar det. 2005" (white label).

Diagnosis: Neralsia cressoni $\mathrm{n}$. sp., together with a $N$. desantisi, $N$. rauli and $N$. marioi, belong to the group of species with low interfoveal carina and metasomal tergum II smooth at base. However, N. cressoni n. sp. is differentiated from $N$. rauli and $N$. marioi, among other characters, by the morphology of the antennae since the last flagellomeres of its antennae are short and sub-cylindrical (Fig. 11B). The differences between $N$. cressoni n. sp. and $N$. desantisi are indicated in the key.

Length: female: $3.4 \mathrm{~mm}$; male: unknown.

Coloration: black. Antennae dark brown; tegulae, legs (except for the coxa that are black) and ventral area of the metasoma reddish. Wings dusky, venation brown.

Head: In frontal view, sub-squared; in dorsal view twice as long as wide. Face with striae that depart radially from the clipeus towards the antennal foveae and inferior part of the compound eyes, surface between them, smooth. Transfacial line 1.1 times the height of the eye. The relation POL:OOL:OCO is $7: 4: 3.5$; diameter of the lateral ocellus 3 . Genal sulcus present, with transversal costulae very marked. Occiput dorsally carinated; genal carina visible behind the compound eyes.

Antennae (Fig. 11B): F1 longer than F2, with no sensilia; the last flagellomeres 1.2 times longer than wide.

Mesosoma (Fig. 5A, B): pronotal plate dorsally incised, lateral areas of the pronotum with sharp carinae, scarce and spaced in the dorsal part, denser in the anterior ventral part, the rest smooth. Mesopleura smooth in the middle, dorsal and ventral areas slightly striated. Medial sulcus of the scutum short and visible. Interfoveal carina low, surpassing very slightly the level of the scutellar foveae (lateral view). Scutellar disc more or less ridged, with longitudinal carinae hardly defined that can form or not the scutellar sulcus. Scutellar spine long and coriaceous, its size bigger than $1 / 3$ the total length of the scutellum.

Wings: radial cell 1.5 longer than wide (Fig. 10b). Discal and marginal setae present. Areolet weakly formed.

Metasoma: tergum I wide, strongly carinated. Tergum II completely smooth at base. Dorsal margin of the tergum VIII, in lateral view, weakly concave.

Distribution: species collected from Venezuela. 

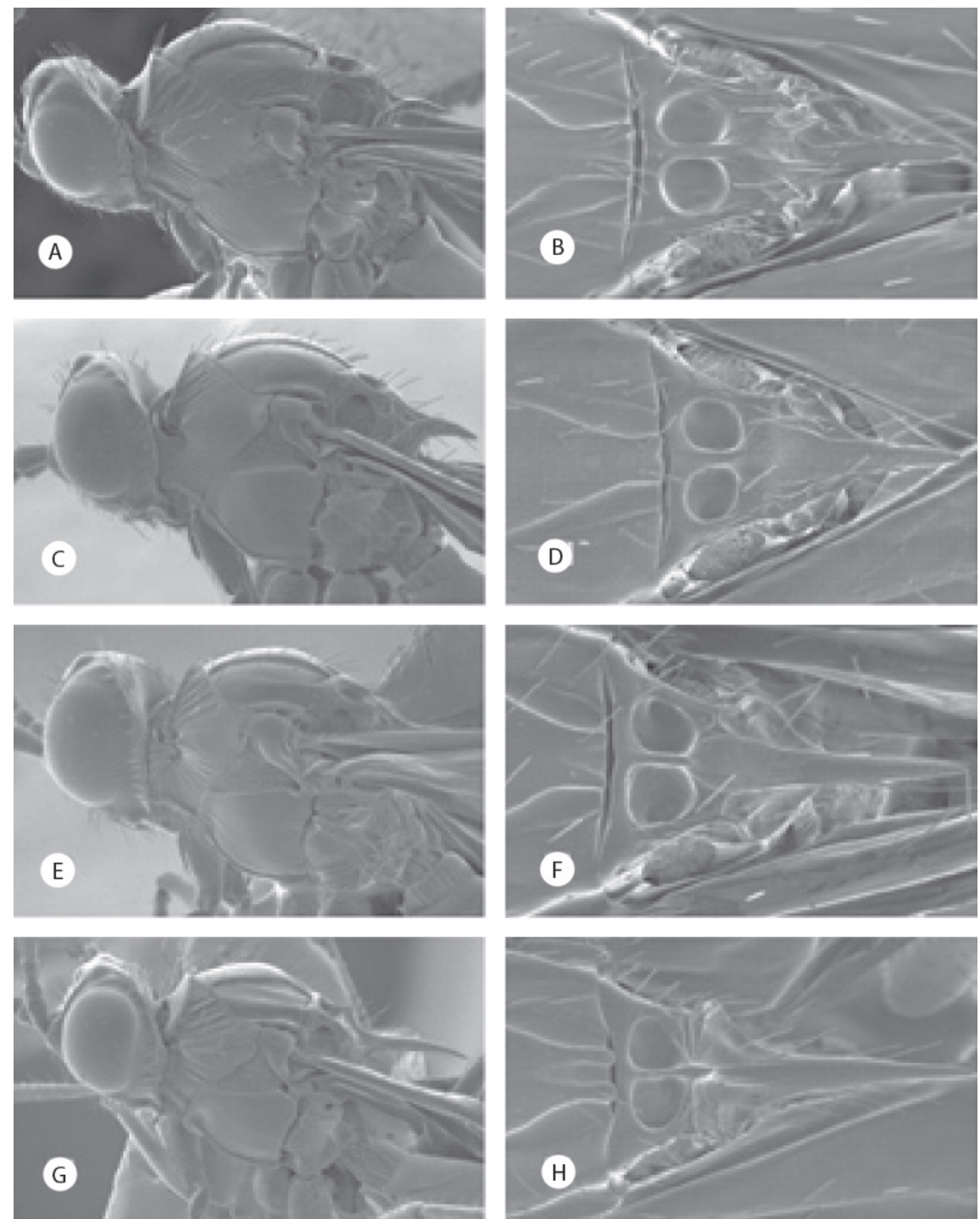

Fig. 5. Cabeza y mesosoma (A, C, E, G) en vista lateral; detalle del escutelo (B, D, F, H) en vista dorsal: Neralsia cressoni n. sp. (A, B), N. rauli (C, D), N. marioi (E, F) y N. ellongata (G, H).

Fig. 5. Head and mesosoma (A, C, E, G) in lateral view; detail of scutellum (B, D, F, H) in dorsal view: Neralsia cressoni n. sp. (A, B), N. rauli (C, D), N. marioi (E, F) y N. ellongata (G, H). 


\section{Neralsia rauli \\ Jiménez and Pujade-Villar 2006}

(Fig. 5C, D, 11T)

Neralsia rauli Jiménez and Pujade-Villar 2006a: 66 .

Studied material: see Jiménez et al. 2006a. Additional material studied. PERU: Pasco, Peru, 1 600-1 800 m, 10³5' S; 7535' W., 30-31.XII.1972, J. Helava. 1 male (CNCI); BRAZIL: Jatai, 30.III.1988, Varr Angélica, Goias, Brazil: 1 male (Angélica).

Diagnosis: Neralsia rauli, belongs to the group of species with low interfoveal carina and metasomal tergum II with scarce and short striae at base. Close to this species are N. desantisi, $N$. cressoni n. sp. and N. marioi. Neralsia rauli presents long antennal flagellomeres (Fig. $11 \mathrm{~T})$ and the medial sulcus is weakly marked (Fig. 5D) different from $N$. desantisi (Fig. 4H, $11 \mathrm{M}$ ) and $N$. cressoni n. sp. (Fig. 5B, 11B) in which the flagellomeres are shorter and the medial sulcus is very marked and visible. The differences between $N$. rauli and $N$. marioi are indicated in the key.

Distribution: species known from Brazil, French Guiana and Peru (Jiménez et al. 2006a).

\section{Neralsia marioi}

Jiménez and Pujade-Villar 2006

(Fig. 5E, F, 11S)

Neralsia marioi Jiménez and Pujade-Villar 2006a: 66

Studied material: see Jiménez et al. 2006a. Additional material studied. ECUADOR: C-396 Napo, Oyacachi, $3150 \mathrm{~m}, 0^{\circ} 22^{\prime} \mathrm{S}, 78.08^{\circ} \mathrm{W}$, 30.II-15.IV.1996, ? Durero, Ecuador (Oriente), 23-28.IX.1997, 150-200 m: 1 female (CNCI); BRAZIL: M. Gerais, Aguas Vermelhas, 800 m, VII.1983, M. Alvarenga: 1 female (CNCI).

Diagnosis: Neralsia marioi belongs to the group of species with low interfoveal carina and the metasomal tergum II with scarce and short carina at base. Close to this species are $N$. desantisi, $N$. cressoni n. sp., and $N$. rauli.
Neralsia marioi presents very long antennal flagellomeres (Fig. 11S) and the medial sulcus of the scutellum slightly marked (Fig. 5F) differently from $N$. desantisi and $N$. cressoni $\mathrm{n}$. sp. where the flagellomeres are shorter (Fig. 11B, $\mathrm{M})$ and the medial sulcus is very marked and visible (Figs. 4H, 5B). The differences between $N$. marioi and $N$. rauli are indicated in the key.

Distribution: species known from Brazil, Ecuador and Venezuela (Jiménez et al. 2006a).

\section{Neralsia ellongata \\ Jiménez and Pujade-Villar 2005 \\ (Fig. 5G, H, 10E, 11W, X)}

Neralsia ellongata Jiménez and Pujade-Villar 2005b:169.

Studied material: see Jiménez et al. 2005b. Additional material studied. BRAZIL: Est. Biol. Boraceia, Salesópolis- S.P. Brazil, XI.1960, K. Lento col: 1 male.

Diagnosis: Neralsia ellongata belongs to the group of species with high interfoveal carina and the metasomal tergum II completely smooth at base. Males of $N$. ellongata as those of $N$. paraellongata are differentiated from the rest of Neralsia species by the relation between F1 and F2. Females of $N$. ellongata are distinguished from the rest of species of the genus by presenting the flagellomeres very long, four times longer than wide (Fig. $11 \mathrm{~W}$ ), and the radial cell elongated, more than twice longer than wide (Fig. 10E). On the other hand, the scutellum spine is longer than half the length of the scutellar disc (Fig. 5H), feature shared only with $N$. paraellongata from which is differentiated by the characters indicated in the key.

Distribution: species widely distributed in South America; known from Bolivia, Brazil, Ecuador, French Guiana, Peru and Venezuela (Jiménez et al. 2005b).

Observations: when described $N$. ellongata in Jiménez et al. (2005b: 171) it is erroneously said that the radial cell is closed, when it is actually open in the frontal margin; this structure presents a darkening that should not be considered as a vein. 
Neralsia paraellongata

Jiménez and Pujade-Villar 2005

(Fig. 10F, 11Y)

Neralsia paraellongata Jiménez and PujadeVillar 2005b: 175.

Studied material: see Jiménez et al. 2005b.

Diagnosis: Neralsia paraellongata belongs to the group of species with high interfoveal carina and metasomal tergum II smooth at base. N. paraellongata and N. ellongata are very close species; males of both species are differentiated by the relative length between F1 and F2, which is 0.8 in N. paraellongata and 0.5-0.6 in N. ellongata. This feature separates also $N$. paraellongata from all the other known species of Neralsia, in which the males present a similar length between the aforementioned flagellomeres. Despite the females of $N$. paraellongata are unknown, we suspect that they have to show very long flagellomeres as in $N$. ellongata due to the morphological similarity between the males of both species.

Distribution: species only known from Brazil (Jiménez et al. 2005b).

Observations: erroneously, when describing N. paraellongata in Jiménez et al. (2005b: 176) it is said that the radial cell is closed, while it is actually open in the frontal margin, this presenting a darkening that should not be considered as a vein.

\section{Neralsia scutellata}

Jiménez and Pujade-Villar 2005

(Fig. 6A, B)

Neralsia scutellata Jiménez and Pujade-Villar 2005b: 176.

Studied material: see Jiménez et al. 2005b.

Diagnosis: Neralsia scutellata belongs to the group of species with high interfoveal carina and it is differentiated from all the other species that share this feature by presenting the scutellar spine shorter. It is distinguished from the rest of South American species of the genus by the shape of the scutellum, as this, in lateral view, is sub-squared.

Distribution: species known from Brazil, Colombia and Venezuela (Jiménez et al. 2005b).

\section{Neralsia magnum}

Jiménez and Pujade-Villar, 2005

(Fig. 6C, D, 11P)

Neralsia magnum Jiménez and Pujade-Villar 2005b: 174.

Studied material: see Jiménez et al. 2005b.

Diagnosis: Neralsia magnum is the biggest species of the South American Neralsia, belonging to the group presenting high interfoveal carina. Its morphological characters set it close to $N$. dianae and $N$. claripennis; all of them have in common the interfoveal carina in the shape of blunt tooth. Neralsia magnum is differentiated from the mentioned species, besides because of its big size, because of the shape of the antennal flagellomeres (Fig. $11 \mathrm{P}-\mathrm{R})$, it is the only one that presents the lateral margins of the scutellum at the same level of the interfoveal carina.

Distribution: species only known from Brazil (Jiménez et al. 2005b).

Neralsia claripennis

(Dettmer 1932) (Fig. 6E, F)

Xyalophora claripennis Dettmer 1932: 124, 137.

Neralsia claripennis (Dettmer 1932) Weld 1952: 176.

Studied material: see Jiménez et al. 2004.

Diagnosis: re-described in Jiménez et al. 2004: 70. Neralsia claripennis belongs to the group of species with high interfoveal carina and metasomal tergum II densely striated in the base. In this species the genal sulcus is scarcely defined and presents no costulae (Fig. 6E), 

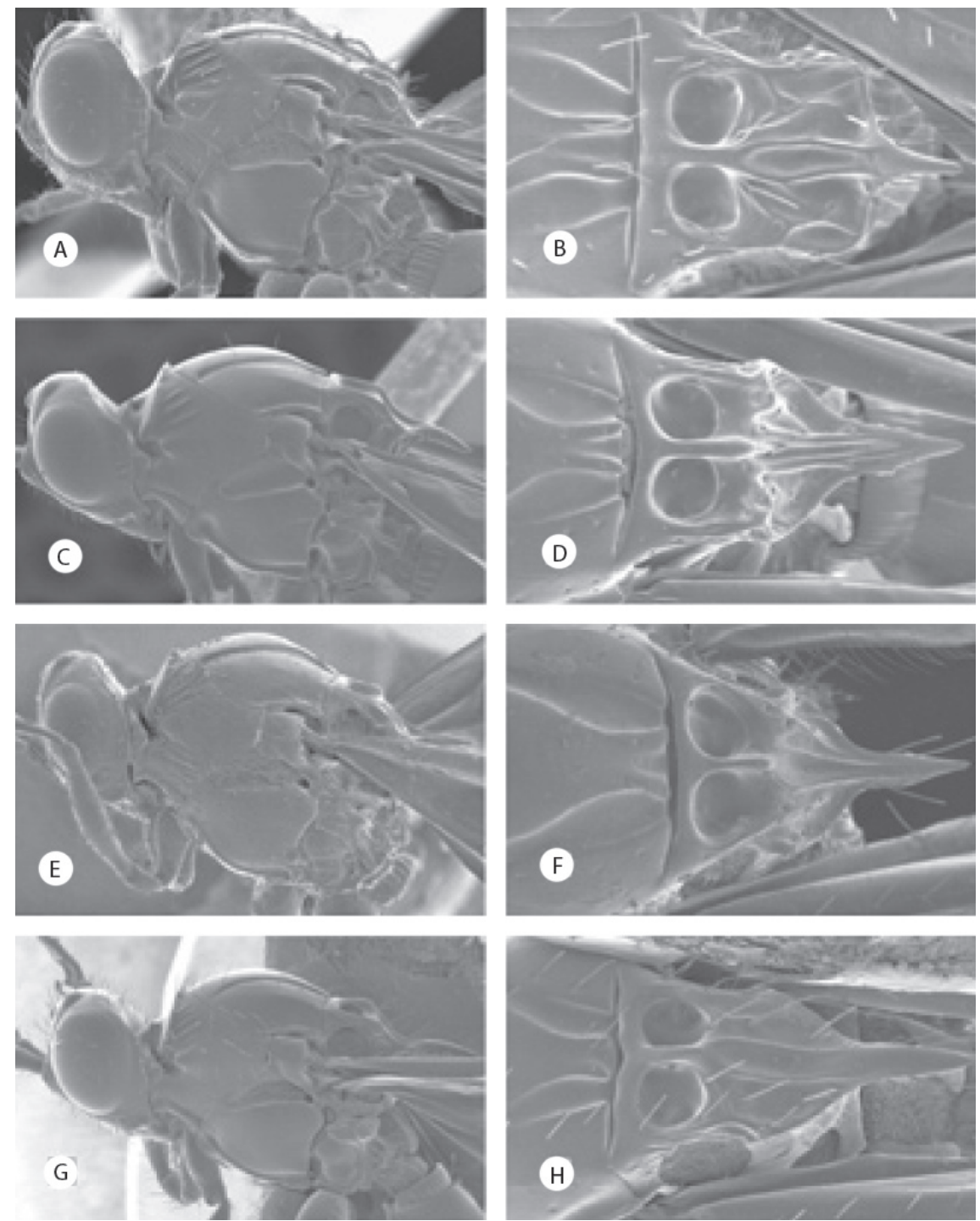

Fig. 6. Cabeza y mesosoma (A, C, E, G) en vista lateral; detalle del escutelo (B, D, F, H) en vista dorsal: Neralsia scutellata (A, B), N. magnum (C, D), N. claripennis (E, F) y $N$. dianae $(\mathrm{G}, \mathrm{H})$.

Fig. 6. Head and mesosoma (A, C, E, G) in lateral view; detail of scutellum (B, D, F, H) in dorsal view: Neralsia scutellata (A, B), N. magnum (C, D), N. claripennis (E, F) y N. dianae (G, H). 
feature only shared with $N$. dianae (Fig. 6G) that presents scarce or absent striation of the metasomal tergum II and wings dusky at base. Neralsia claripennis and $N$. fossulata are the only South American species with hyaline wings and with pale yellow veins.

Distribution: known species only from Brazil. It has not been further collected since its description.

Observations: when $N$. claripennis is redescribed in Jiménez et al. (2004: 70) the coloration of the wings is erroneously mentioned as dusky.

\section{Neralsia dianae}

Jiménez and Pujade-Villar 2005

(Fig. 6G, H, 11Q)

Neralsia dianae Jiménez and Pujade-Villar 2005b: 168 .

Studied material: see Jiménez et al. 2005b.

Diagnosis: Neralsia dianae belongs to the group of species with high interfoveal carina; as in N. magnum and N. claripennis the aforementioned carina has the shape of a blunt tooth. Neralsia dianae is distinguished from $N$. magnum, by the shape of the last flagellomeres (Fig. 11Q) and by presenting the lateral margins of the scutellum lower than the interfoveal carina. The differences between $N$. dianae and $N$. Claripennis are indicated in the key.

Distribution: species only known from French Guiana (Jiménez et al. 2005b).

\section{Neralsia unicarenata}

Jiménez and Pujade-Villar n. sp.

(Fig. 7A, B, 10L, 11F)

Etymology: the name of this species alludes to the presence of a single central carina noticeable in the disc of the scutellum.

Type material: holotype (female) deposited in DCBU (Sao Carlos, Brazil) BRAZIL: "Ubatuba est. Exp., 19.VI.1990 Moer, N.F.de Cristo, Col. Angélica" (white label); Holotype desig.-2005 Jiménez and Pujade-Villar" (red label), "Neralsia unicarenata" n. sp female
Jiménez and Pujade-Villar det. 2005" (white label). Paratypes: VENEZUELA: Mt. Ruida, Venezuela, 4.XI.1928, Ac. 29500, Tate, No.89: 1 female (NY); Jatai, 30.III.1988, varr. Angélica: 1 female (Angélica).

Diagnosis: Neralsia unicarenata n. sp., presents the scutellum with a single central carina between the foveae and the spine; it seems to be the fusion of the two carinae that form the typical sulcus of the scutellum of all Neralsia, or a prolongation of the interfoveal carina till the base of the spine.

Length: females: $2.4-3.3 \mathrm{~mm}$; males: unknown.

Coloration: black. Antennae reddish brown; tegulae, legs and ventral part of the metasoma reddish. Translucent wings, venation light brown.

Head: in frontal view oval; in dorsal view 2.4 times longer than wide. Face with striae that depart radially from the clipeus towards the antennal foveae, surface between them smooth, around the compound eyes coriaceous. Transfacial line 1.2 times the height of the eye. The relation POL:OOL:OCO is 7:4:5, diameter of the medial ocellus 3. Genal sulcus defined with transversal costulae marked. Occiput weakly carinated in the dorsal part; genal carina visible behind the compound eyes.

Antennae (Fig. 11F). F1 longer than F2; last flagellomeres 1.4 times longer than wide. Sensilia absent in F1, F2 and F3.

Mesosoma (Fig. 7A, B): pronotal plate dorsally incised, lateral areas of the pronotum with scarce carinae sharp and spaced in the dorsal part, only a bit denser in the anterior ventral part, the rest smooth. Mesopleura smooth in most of its surface, ventral part slightly striated. Medial sulcus of the scutum marked. Interfoveal carina in shape of a sharp tooth that surpasses the level of the scutellar foveae (lateral view). Scutellar disc slightly carinated, being noticed an apparent prolongation of the carina that separate the foveae and that longitudinally crosses the scutellum until the base of the spine without forming a sulcus. Scutellar spine long, its size $1 / 3$ of the total length of the scutellum. 

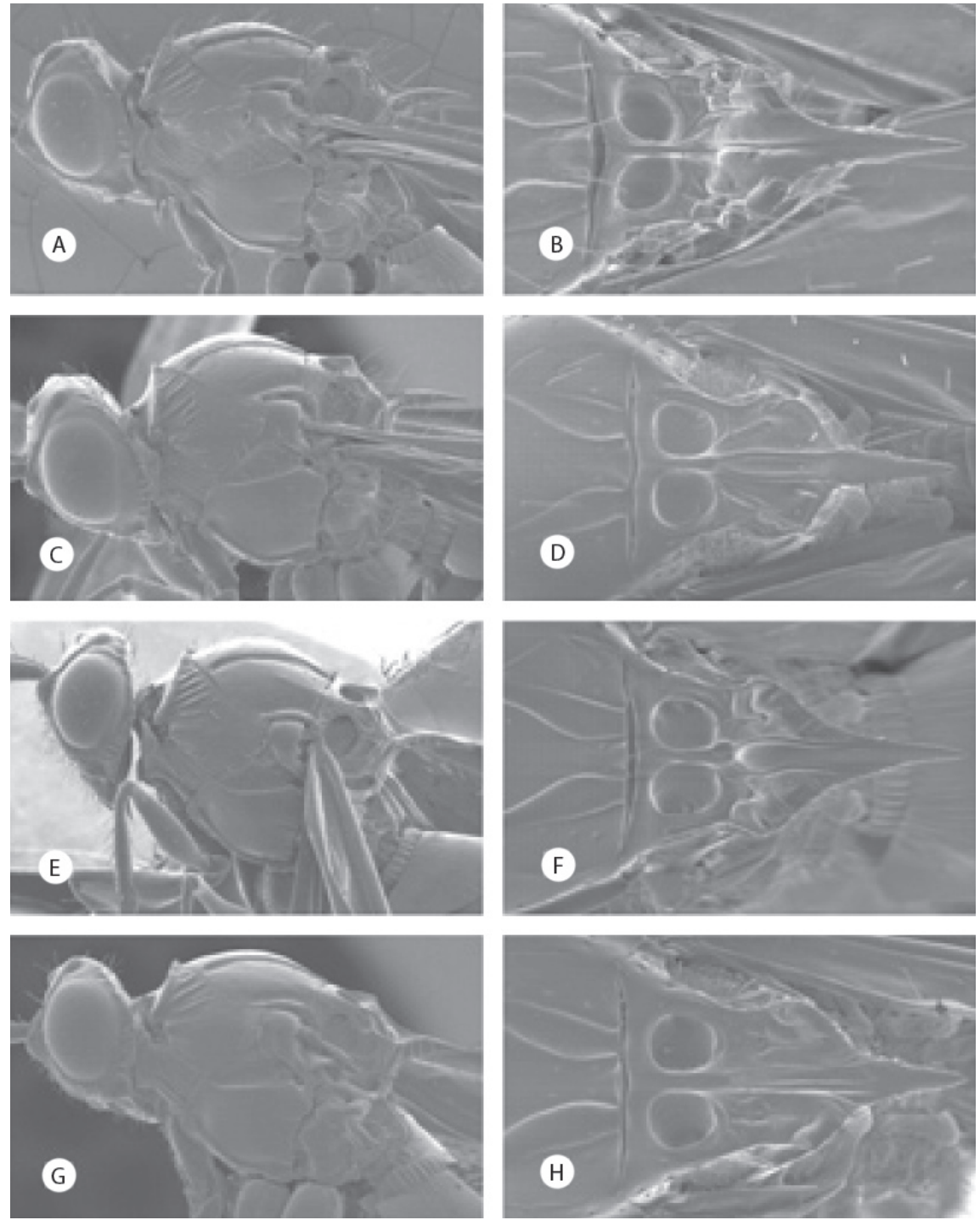

Fig. 7. Cabeza y mesosoma (A, C, E, G) en vista lateral; detalle del escutelo (B, D, F, H)en vista dorsal: Neralsia unicarenata n. sp. (A, B), N. madrigalensis n. sp. (C, D), N. francisi (E, F) y N. gracielae (G, H).

Fig. 7. Head and mesosoma (A, C, E, G) in lateral view; detail of scutellum (B, D, F, H) in dorsal view: Neralsia unicarenata n. sp. (A, B), N. madrigalensis n. sp. (C, D), N. francisi (E, F) y N. gracielae $(\mathrm{G}, \mathrm{H})$. 
Wings: radial cell 1.5 times longer than wide (Fig. 10L). Discal and marginal setae present. Areolet absent.

Metasoma: tergum I narrow, strongly carinated. Tergum II densely and uniformly striated at base. Dorsal margin of tergum VIII, in lateral view, strongly incised.

Distribution: species collected from Brazil and Venezuela.

\author{
Neralsia madrigalensis \\ Jiménez and Pujade-Villar n. sp. \\ (Fig. 7C, D, 10J, 11E)
}

Etymology: species dedicated to Dr. Alejandro Madrigal Cardeño, entomologist of the Universidad Nacional de Colombia (Medellín).

Type material: holotype (female) deposited in (CNCI) BRAZIL: "M.Gerais, Agua Vermelha, 800 m, VII.1983, M. Alvarenga" (white label); Holotype desig.-2005 Jiménez and Pujade-Villar" (red label), "Neralsia madrigalensis" n. sp female Jiménez and PujadeVillar det. 2005" (white label). Paratype: ARGENTINA: Punta Lara, III.1974, Díaz Col.: female (MLP).

Diagnosis: Neralsia madrigalensis n. $\mathrm{sp}$. belongs to the group of species with high interfoveal carina and metasomal tergum II striated at base. This species is close to $N$. unicarenata n. sp., $N$. francisi, $N$. gracielae, $N$. suffecta and $N$. alonsoi $\mathrm{n}$. sp. Neralsia madrigalensis $\mathrm{n}$. $\mathrm{sp}$. is differentiated from $N$. unicarenata. $\mathrm{n}$. sp. as the latter presents a single main carina very visible over the scutellar disc (Fig. 7B). The flagellomeres are long (Fig. 11E) and the face with striae departing radially from the clipeus towards the antennal foveae and the inferior part of the compound eyes separate $N$. madrigalensis $\mathrm{n}$. $\mathrm{sp}$. from the rest of the mentioned species.

Length: females: $2.4-3.3 \mathrm{~mm}$; males: unknown.

Coloration: black. Antennae brown; tegulae, legs and ventral part of the metasoma reddish. Wings dusky; venation brown.

Head: in frontal view oval; in dorsal view twice longer than wide. The face of the female with striae that depart radially from the clipeus towards the antennal foveae and the inferior part of the compound eyes; surface between the striae smooth. Transfacial line equal in length to the height of the compound eye. The relation POL:OOL:OCO is 7.5:4:4.5, diameter of the lateral ocellus 3.5. Genal sulcus defined with transversal costulae marked. Occiput dorsally carinated; genal carina visible behind the compound eyes.

Antennae (Fig. 11E): filiform, F2, F3 and F4 of the same size, approximately 2.6 times longer than wide and of bigger length than F1, last flagellomeres 1.8 times longer than wide. Sensilia absent in F1.

Mesosoma (Fig. 7C, D): pronotal plate dorsally incised, lateral areas of the pronotum with scarce sharp carina in the dorsal part, thinner and denser in the anterior ventral part, the rest smooth. Mesopleura smooth in the middle, dorsal and ventral part, thinly striated. Medial sulcus of the pronotum short, wide and flat. High interfoveal carina, in shape of a sharp tooth, surpassing by far the level of the scutellar foveae (lateral view). Scutellar disc carinated, being noticed two carina heading towards the spine, forming between them a defined and smooth sulcus. Scutellar spine long, thick and coriaceous, ending in a sharp end, its size bigger than $1 / 3$ the total length of the scutellum.

Wings: radial cell 1.5 times longer than wide (Fig. 10J). Discal and marginal setae present. Areolet almost formed.

Metasoma: tergum I wide, strongly carinated. Tergum II densely striated at base. Dorsal margin of the tergum VIII, in lateral view, strongly incised.

Distribution: species collected from Argentina and Brazil

Neralsia francisi

Jiménez and Pujade-Villar 2005

(Fig. 7E, F, 11N)

Neralsia francisi Jiménez and Pujade-Villar 2005b: 171

Studied material: see Jiménez et al. 2005 b. Additional material studied. ECUADOR: C-396 
Napo. Oyacachi, 3150 m, 022' S, 78.08 ${ }^{\circ} \mathrm{W}$, 30.II-15.IV.1996, ? ;Durero, Ecuador (Oriente), 23-28.IX.1997, 150-200 m: 1 female (CNCI), C-394, Ecuador, Sucumbios. Napo River Sacha Lodge, 030' S y 76 $36^{\circ}$ ' W, 270 m, 3-25. VII. 1999, Meter Hibbs, MT: 1 male (CNCI); BRAZIL: Santana F. Dos, Macacos, PA, Brazil, IX.1969, Exp. Perm. Amax.: 1 female (CNCI); ARGENTINA: Loreto, Misiones, Republica Argentina. Dr. A.A. Ogloblin, 12.IX.1934: 1 male (MLP);

Diagnosis: Neralsia francisi belongs to the group of species with high interfoveal carina and the metasomal tergum II densely striated at base. It is close to $N$. unicarenata., n. sp., $N$. madrigalensis n. sp., $N$. gracielae, $N$. suffecta and $N$. alonsoi $\mathrm{n}$. sp. Neralsia unicarenata. $\mathrm{n}$. sp. is differentiated, among other characters, by having a single, very visible, carina in the scutellar disc (Fig. 7B). Neralsia madrigalensis n. sp. by presenting the flagellomeres extremely long (Fig. 11E). Neralsia alonsoi n. sp. and $N$. suffecta, have antennal flagellomeres (Fig. $11 \mathrm{~N}$ ) shorter (Fig. 11A, U) than N. francisi, species where the flagellomeres are moderately long. Finally, the differences between N. francisi and $N$. gracielae are indicated in the key.

Distribution: species known from Argentina, Brazil, Ecuador, Paraguay y Peru (Jiménez et al. 2005b).

Neralsia gracielae

Jiménez and Pujade-Villar 2005

(Fig. 7G, H, 11O)

Neralsia gracielae Jiménez and Pujade-Villar 2005b: 172

Studied material: see Jiménez et al. 2005b. Additional material studied. ARGENTINA: Loreto, Exp. St., Misiones Arg., Dr. A.A. Ogloblin, 15.III.1932: 1 male and 2 females (MLP); idem except for the date of recollection, 17.III.1932: 1 female (MLP); BRAZIL: Minas Gerais, Sinop. XI.1975, M. Alvarenga. M.T.: 1 female (CNCI); Mata Canchim, 3.X-16.X.1997, Malaise: 1 male (CNCI).
Diagnosis: Neralsia gracielae, belongs to the group of species with high interfoveal carina and the metasomal tergum II striated a base, it is close to $N$. unicarenata. n. sp., $N$. madrigalensis n. sp., N. francisi, N. suffecta and $N$. alonsoi n. sp. Neralsia unicarenata. $\mathrm{n}$. sp. is differentiated, among other characters, by having a single, very visible, carina in the scutellar disc (Fig. 7B), the flagellomeres are extremely long (Fig. 11E) and face with striae that depart radially from the clipeus towards the antennal foveae and the inferior part of the compound eyes. Neralsia alonsoi n. sp. and $N$. suffecta, have short antennal flagellomeres (Fig. 11A, U) differently to $N$. gracielae where are moderately long (Fig. 11O). The differences between $N$. gracielae and $N$. francisi are indicated in the key.

Distribution: species known from Colombia (Jiménez et al. 2005b). In this study it is also cited from Argentina and Brazil.

Neralsia suffecta

(Dettmer 1932) (Fig. 8A, B, 11U)

Xyalophora suffecta Dettmer 1932: 124, 131

Neralsia suffecta (Dettmer 1932) Weld 1952: 177

Studied material: see Jiménez et al. 2004. Additional material studied. COLOMBIA: Quindío, 1 Kms, Calarcá, for, 8-10.III.1974, 5000', S and J. Peck, DT990-2: 2 females (CNCI); VENEZUELA: Mérida, Mérida Sta. Rosa, 2000 m, 15.VI-15.VII. 1981, pantraps, A. Briceño and F. Suárez: 2 females (CNCI); Mérida, Mérida Sta. Rosa, 2000 m, 15.VI-15.

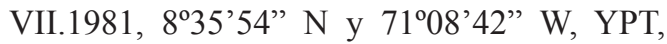
A. Briceño y F. Suárez: 2 females (CNCI); Mérida, Mérida Sta. Rosa, 2 000m, 8 35'54" $\mathrm{N}$ y $71^{\circ} 08^{\prime} 42^{\prime \prime}$ W, 15.VI-15.VII.1981, sep in cloud for, pasture, Masner y Marsh 8111: 1 male (CNCI); Mérida, Tabay La Mucuy, 1 900m, 18.VI-2.VIII.1989, S.J. Peck, M.T., Streamside meadow: 2 males (CNCI); C-156 A Edo Aragua, Cerro el Café, 1 200m, 10 Km NW Valencia, 23-26-II.1971,s.Peck, forest humandung t: 2 albino females (CNCI); C-156, 

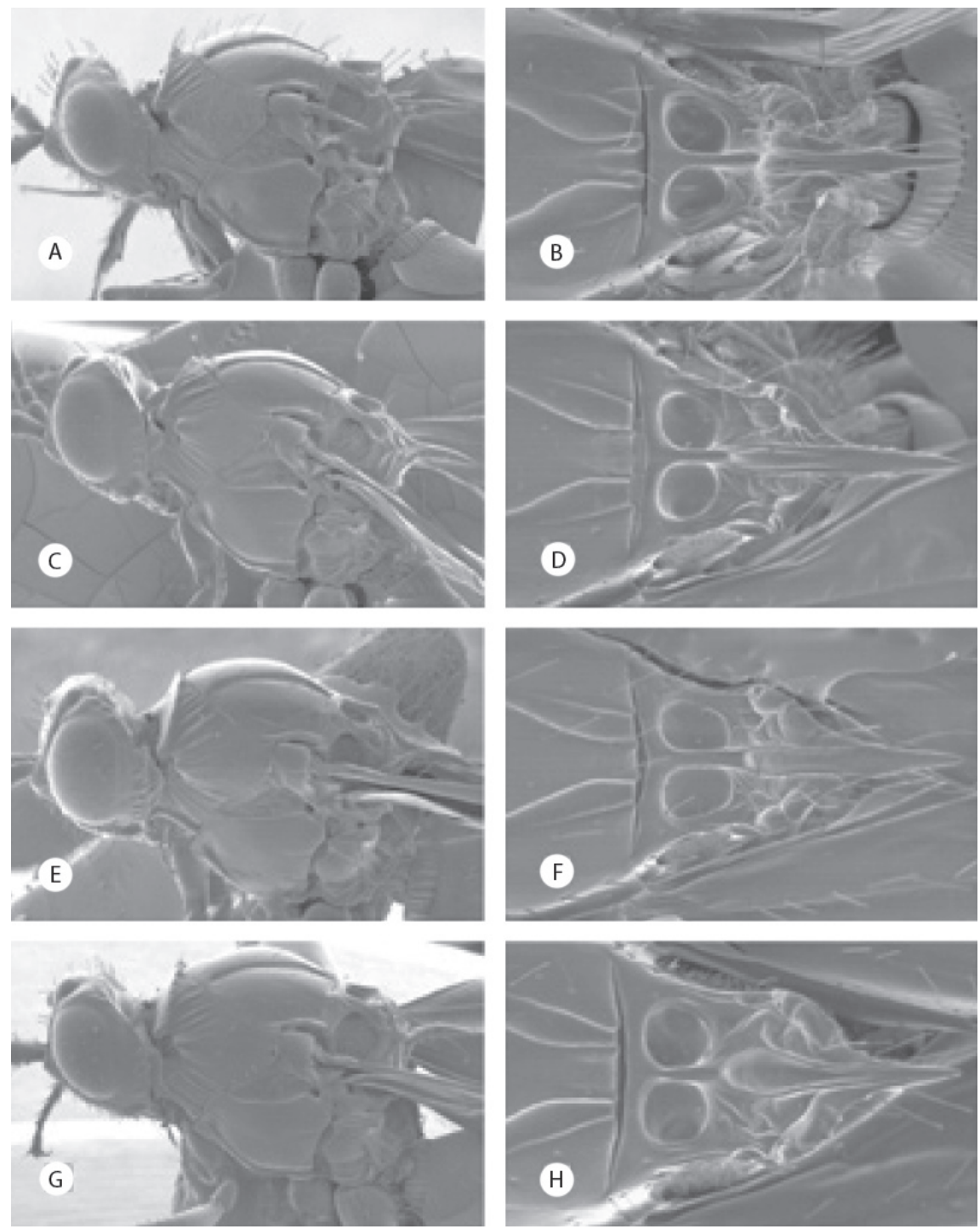

Fig. 8. Cabeza y mesosoma (A, C, E, G) en vista lateral; detalle del escutelo (B, D, F, H) en vista dorsal: Neralsia suffecta (A, B), N. alonsoi n. sp. (C, D), N. vickyae (E, F) y N. obelix (G, H).

Fig. 8. Head and mesosoma (A, C, E, G) in lateral view; detail of scutellum (B, D, F, H) in dorsal view: Neralsia suffecta (A, B), N. alonsoi n. sp. (C, D), N. vickyae (E, F) y N. obelix (G, H). 
Venezuela, A. Edo. Aragua. Centro el café, 1 200m, 10 Km NW, Valencia, 23-26.II.1971, s. Peck forest humandung t: 2 females (CNCI); ECUADOR: Napo, 12 Km S.W. Tena, 500 m, 8-11.VII.1976, S. and J. Peck: 1 male (CNCI).

Diagnosis: Neralsia suffecta belongs to the group of species with high interfoveal carina and metasomal tergum II strongly striated at base. It is close to N. madrigalensis $\mathrm{n}$. sp., $N$. francisi, $N$. gracielae and $N$. alonsoi $\mathrm{n}$. sp. From which is differentiated by the features of the scutellar disc.

Distribution: species widely distributed in South America, known from Argentina, Brazil, Bolivia, Colombia, Ecuador, Paraguay, Peru and Venezuela (Jiménez et al. 2004).

\section{Neralsia alonsoi \\ Jiménez and Pujade-Villar n. sp. \\ (Fig. 8C, D, 10A, 11A)}

Etymology: species dedicated to the first of the author's father (Alonso Jiménez)

Type material: holotype. (female) deposited in UB "Felix, MEI, 29. IV.96" (white label); Holotype desig.-2004 Jiménez and Pujade-Villar" (red label), "Neralsia alonsoi n. sp female Jiménez and Pujade-Villar det. 2004" (white label). Paratypes (2 males and 11 females): BRAZIL: Caruaru, $900 \mathrm{~m}$, Pernambuco, V.1972, J. Lima: 1 male (CNCI); Mata Canchim, 4.IV.97: 1 female (DCBU); Petrópolis, R Ueter, Nou gen. Borgmeier 193?, Xyalophora n. sp female. Det. Borgmeier 193?, X.1937: 1 female (MNRJ); Nova Teutonia, $27^{\circ} 11^{\prime}$ S-52 $23^{\prime}$ W, Brazil, 300-500 m, 3.IV.1971, Fritz Plaumam: 1 female (CNCI); BOLIVIA: La Paz: Alto Río Beni, south of Rio Inicua, 1100 m. January 15-18, 1976, L.E. Peña: 2 females (AMNH); COLOMBIA: Valle, Above Saladido, 6 500', 8.IV.1971, Eberhard and García: 1 female (CNCI); ECUADOR: CSucumbios, Napo River, Socha Lodge, $0^{\circ} 30^{\prime}$ $\mathrm{S}$ y 76³0' W $270 \mathrm{~m}, 3-25$.VII.1999, Peter Hibbs, MT: 1 male and 1 female (CNCI); Napo Limonocha, 250 m, 15-28.VI.1976: 1 female (CNCI); PARAGUAY: Itapón, Karonay. S.
Rafael Reserve, 18-20.X.2000, Z.H. Falin Fit: 1 female (CNCI).

Diagnosis: Neralsia alonsoi $\mathrm{n}$. sp., belongs to the group of species with high interfoveal carina and metasomal tergum II striated at base. The closest species are N. unicarenata., n. sp., $N$. madrigalensis n. sp., $N$. francisi, $N$. gracielae, and N. suffecta. It is differentiated from $N$. unicarenata n. sp., among other features, because this one only presents a single carina in the scutellar disc (Fig. 7B). In N. alonsoi n. sp. The flagellomeres are very short (Fig. 11A), differently from $N$. madrigalensis n. sp., $N$. francisi and $N$. gracielae, in which the relation between them is bigger. On the other hand, $N$. alonsoi $\mathrm{n}$. sp. is separated from all the rest of species mentioned because the metasomal tergum VIII, in lateral view, is concave (similar to figure 12J) while in the rest, is incised (similar to figure $12 \mathrm{~K}$ ).

Length. Females: $3.4-3.7 \mathrm{~mm}$, males:

\section{2-3.4 mm}

Coloration: black, except for the antennae, that are reddish brown. Tegulae, legs and ventral part of metasoma reddish. Wings dusky, venation brown.

Head: in frontal view slightly oval, in dorsal view 1.2 times longer than wider. Transfacial line 1.1 times longer than the height of the eye. The relationship POL:OOL:OCO is 8:6:4:5, the diameter of the lateral ocellum is 4 . Genal sulcus present, transversal costulae marked.

Antennae (Fig. 11A): females with F1 and F2 without sensilia and of the same size, bigger than the following; F3 with scarce sensilia, the last flagellomeres sub-squared, as long as wide.

Mesosoma (Fig. 8C, D): pronotum with scarce sharp carinae in dorsal and ventral anterior part, the rest smooth. Mesopleura smooth in most of the surface, with some striae in the posterior and anterior extreme. Medial sulcus very marked. Interfoveal carina forming a blunt tooth and surpassing the level of scutellar foveae. Scutellar disc carinated with two carinae emerging that begin at the interfoveal and head towards the spine forming between them a smooth sulcus; parallel to these, the disc present other carinae that reach its posterior 
edge. Scutellar spine long, sharp and shining, its size approximately $1 / 3$ the total length of the scutellum.

Wings: radial cell 1.5 times longer than wider (Fig. 10A). Marginal setae deciduous and discals very scarce. Areolet missing.

Metasoma: tergum I with gross carinae. Tergum II with striae at base, scarce and short in the lateral part, not always easy to see in the dorsal part. Dorsal margin of the tergum VIII concave in lateral view.

Distribution: species of presumably wide distribution in South America. It has been collected from Brazil, Bolivia, Colombia, Ecuador and Paraguay.

\section{Neralsia vickyae \\ Jiménez and Pujade-Villar 2005}

(Fig. 8E, F, 11V)

Neralsia vickyae Jiménez and PujadeVillar 2005b:178.

Studied material: see Jiménez et al. 2005b. Additional material studied. ECUADOR: C-396 Napo. Oyacachi, 3 150m, $0^{\circ} 22^{\prime} \mathrm{S}, 78.08^{\circ} \mathrm{W}, 30 . \mathrm{II}-15 . \mathrm{IV} .1996$, ? Durero Ecuador (Oriente), 23-28.IX.1997, 150-200 m: 1 female (CNCI); C-369 Sucumbios, Napo, River, Sacha Lodge, $270 \mathrm{Km}, 0^{\circ} 30^{\prime} \mathrm{S}-76^{\circ} 30^{\prime}$ W, 4-14.III.1994 P. Hibbs, Mt: 1 male (CNCI); Ecuador, Pich., 47 km S. Sto. Domingo, Rio Palenque Sta. 22-31.VI.1976, S. \& J. Peck: 1 female (CNCI); BRAZIL: M. Gerais, Sinop, XI.1976 M. Alvarenga, MT: 1 female (CNCI); VENEZUELA: Venezuela, Rancho Grande, 12-30.XII.1987, M. Sanborne, MT: 1 female (CNCI).

Diagnosis: Neralsia vickyae, belongs to the group of species with high interfoveal carina and metasomal tergum II with scarce striae at base. The closest species are $N$. obelix and $N$. dettmeri $\mathrm{n}$. sp. The length and dark coloration of its antennae and the sharp shape of the interfoveal carina (Fig. 8E), easily separate it from $N$. obelix. The longer flagellomeres and the genal costulae hardly marked (Fig. 8E, $11 \mathrm{~V}$ ) set it away from $N$. dettmeri n. sp. (Fig. 9A, 11C).
Distribution: species known from Bolivia, Ecuador and Venezuela (Jiménez et al. 2005b). In this survey it is also cited from Brazil.

\section{Neralsia obelix \\ Jiménez and Pujade-Villar 2006}

(Fig. 8G, H)

Neralsia obelix Jiménez and Pujade-Villar 2006a: 65.

Studied material: see Jiménez et al. 2006a. Additional material studied. BOLIVIA: Santa Cruz 5 mi. N. Santa Cruz, 27.III.1976 C.R. Ward, EX: General collection 1 male (SINM).

Diagnosis: Neralsia obelix, belongs to the group of species presenting high interfoveal carina. The closest species are $N$. vickyiae and $N$. dettmeri n. sp. because they present the metasomal tergum II smooth or with scarce striae at base. The big size and reddish coloration of the antennae of $N$. obelix set it away from $N$. vickyae. The differences between $N$. obelix and $N$. dettmeri n. sp. are indicated in the key.

Distribution: species known from Argentina (Jiménez et al. 2006a). In this study it is also cited from Bolivia.

Observations: Neralsia obelix was erroneously described in Jiménez et al. (2006a: 65) as belonging to the group of species with low interfoveal carina. Only a single specimen presents the aforementioned carina unusually low, probably owing to an individual malformation.

$$
\begin{gathered}
\text { Neralsia dettmeri } \\
\text { Jiménez and Pujade-Villar n. sp. } \\
\text { (Fig. 9A, B, 10C, 11C) }
\end{gathered}
$$

Etymology: species dedicated to the entomologist Rvdo. Heinrich Dettmer (1873-1933) who developed the first revision of the South American species of this genus.

Type material: holotype (female) deposited in CNCI (Ottawa, Canada), BRAZIL: "Minas Gerais, Pedra Azul, XI.1972, M. Alvarenga" (white label), "Holotype desig. 2005, Jiménez and Pujade-Villar" (red label), 

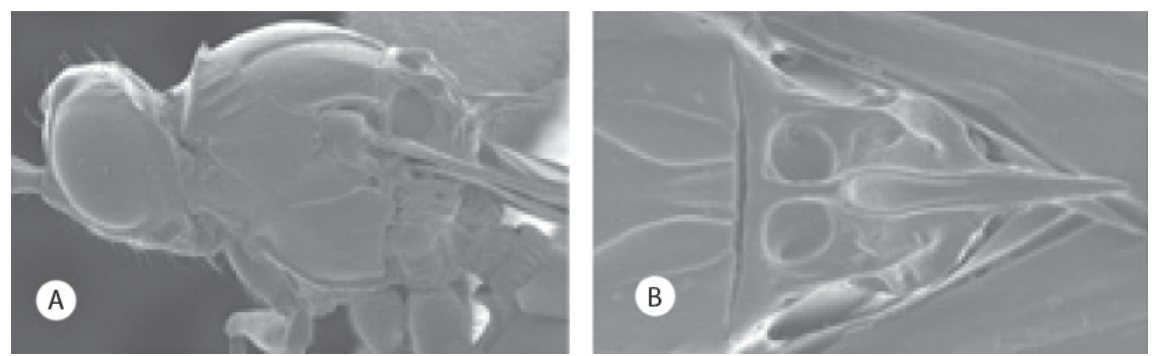

Fig. 9. Cabeza y mesosoma (A) en vista lateral; detalle del escutelo (B) en vista dorsal de Neralsia dettmeri $\mathrm{n}$. sp.

Fig. 9. Head and mesosoma (A) in lateral view; detail of scutellum (B) in dorsal view of Neralsia dettmeri n. sp.

"Neralsia dettmeri n. sp. female Jiménez and Pujade-Villar, det. 2004" (white label). Paratypes: BRAZIL: same data of holotype: 3 females, 2 females CNCI, 1 female UB.

Diagnosis: Neralsia dettmeri $\mathrm{n}$. sp. belongs to the group of species with high interfoveal carina. It is close to $N$. vickyiae and $N$. obelix for they present the metasomal tergum II smooth or with few carinae at base. The length of the flagellomeres and the genal sulcus strongly costulated of $N$. vickyiae (Fig. 8E) allows us to easily differentiate it from $N$. dettmeri $\mathrm{n}$. $\mathrm{sp}$. (Fig. 9A); the differences between the latter and $N$. obelix are indicated in the key.

Length: females: $3.3-3.8 \mathrm{~mm}$; males: unknown..

Coloration: black. Antennae dark brown; tegulae, legs and part of the ventral metasoma reddish. Wings dusky; venation brown.

Head: in frontal view oval; in dorsal view twice longer than wide. The face of the female with striae that depart radially from the clipeus and the middle of the face towards the antennal foveae and inferior part of the compound eyes, surface between them smooth. Transfacial line 0.9 times the height of the eye. The relation POL:OOL:OCO is 7:4:3.5; diameter of the lateral ocellus 3. Genal sulcus defined with tranversal costulae weakly marked or absent. Occiput dorsally carinated; genal carina visible behind the compound eyes.

Antennae (Fig. 11C): F1, F2 and F3 of similar length, the last flagellomeres 1.3 longer than wide. F1 and F2 without sensilia.

Mesosoma (Fig. 9A, B): pronotal plate dorsally entire, lateral areas of the pronotum with scarce sharp carinae and spaced in the dorsal part, denser in the anterior ventral part, the rest smooth. Mesopleura smooth in the majority of the surface, ventral part slightly striated. Medial sulcus of scutum very marked. Interfoveal carina high with the shape of a sharp tooth. Scutellar disc slightly carinated, noticing two carinae that head towards the base of the spine forming between them a well defined smooth sulcus. Scutellar spine long, size higher than $1 / 3$ the total length of the scutellum.

Wings: radial cell 1.8 times longer than wide (Fig. 10C). Discal and marginal setae present. Areolet weakly formed.

Metasoma: tergum I strongly carinated. Tergum II completely smooth or with very few striae at base. Dorsal margin of the tergum VIII, in lateral view, concave. Brazil.

Distribution: species collected from 

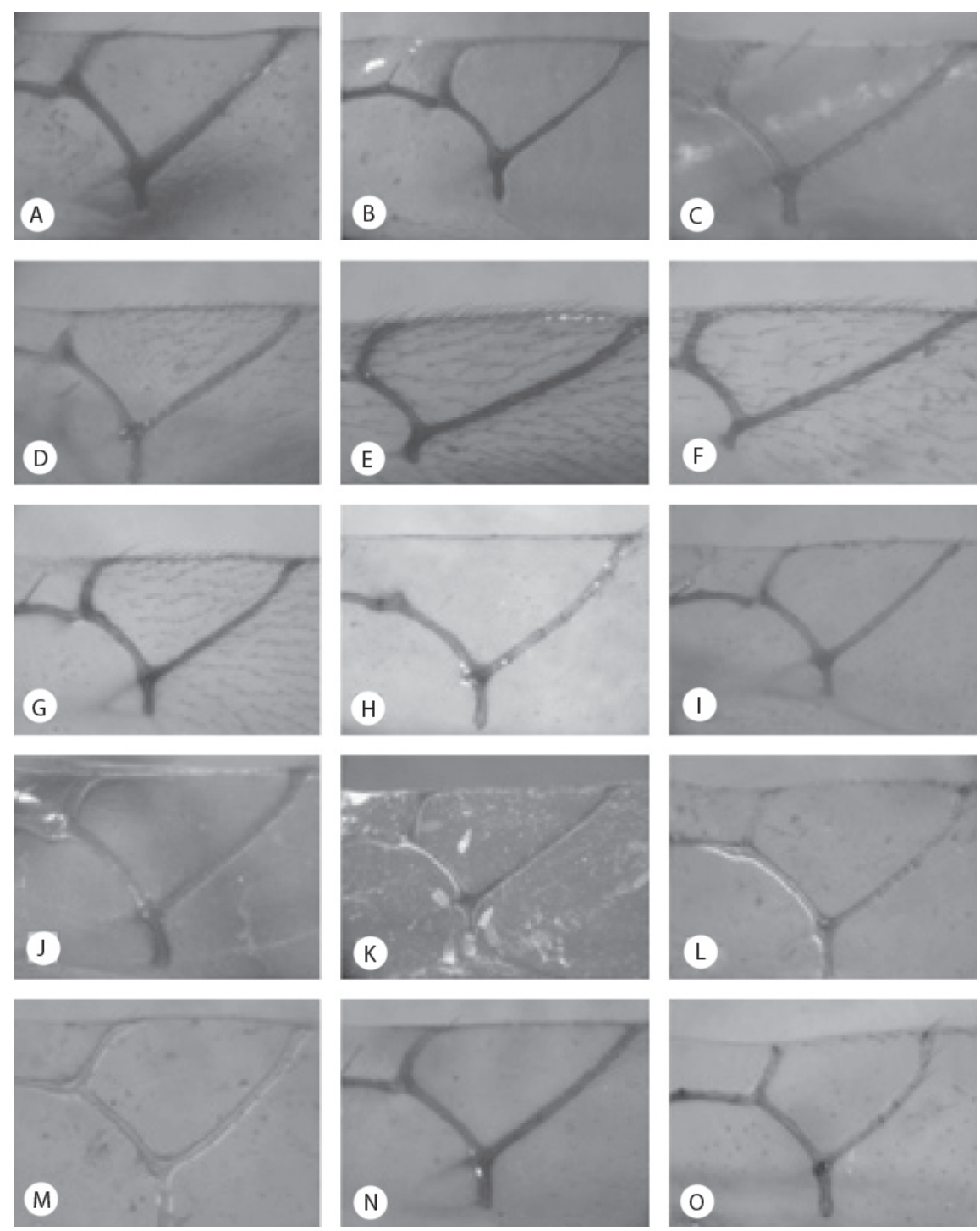

Fig. 10. Celdas radiales: (A) Neralsia alonsoi n. sp., (B) N. cressoni n. sp., (C) N. dettmeri n. sp., (D) N. difilippoi n. sp., (E) $N$. ellongata, (F) N. paraellongata, $(\mathrm{G})$ N. hermaphrodita, $(\mathrm{H}) N$. incompleta, (I) N. julianae $\mathrm{n}$. sp., (J) N. madrigalensis $\mathrm{n}$. sp., (K) N. preta n. sp., (L) N. unicarenata n. sp., (M) N. claripennis, (N) N. dianae y (O) N. parafossulata.

Fig. 10. Radial cells: (A) Neralsia alonsoi n. sp., (B) N. cressoni n. sp., (C) N. dettmeri n. sp., (D) N. difilippoi n. sp., (E) N. ellongata, (F) N. paraellongata, (G) N. hermaphrodita, (H) N. incompleta, (I) N. julianae n. sp., (J) N. madrigalensis $\mathrm{n}$. sp., (K) N. preta n. sp., (L) N. unicarenata n. sp., (M) N. claripennis, (N) N. dianae y (O) N. parafossulata. 

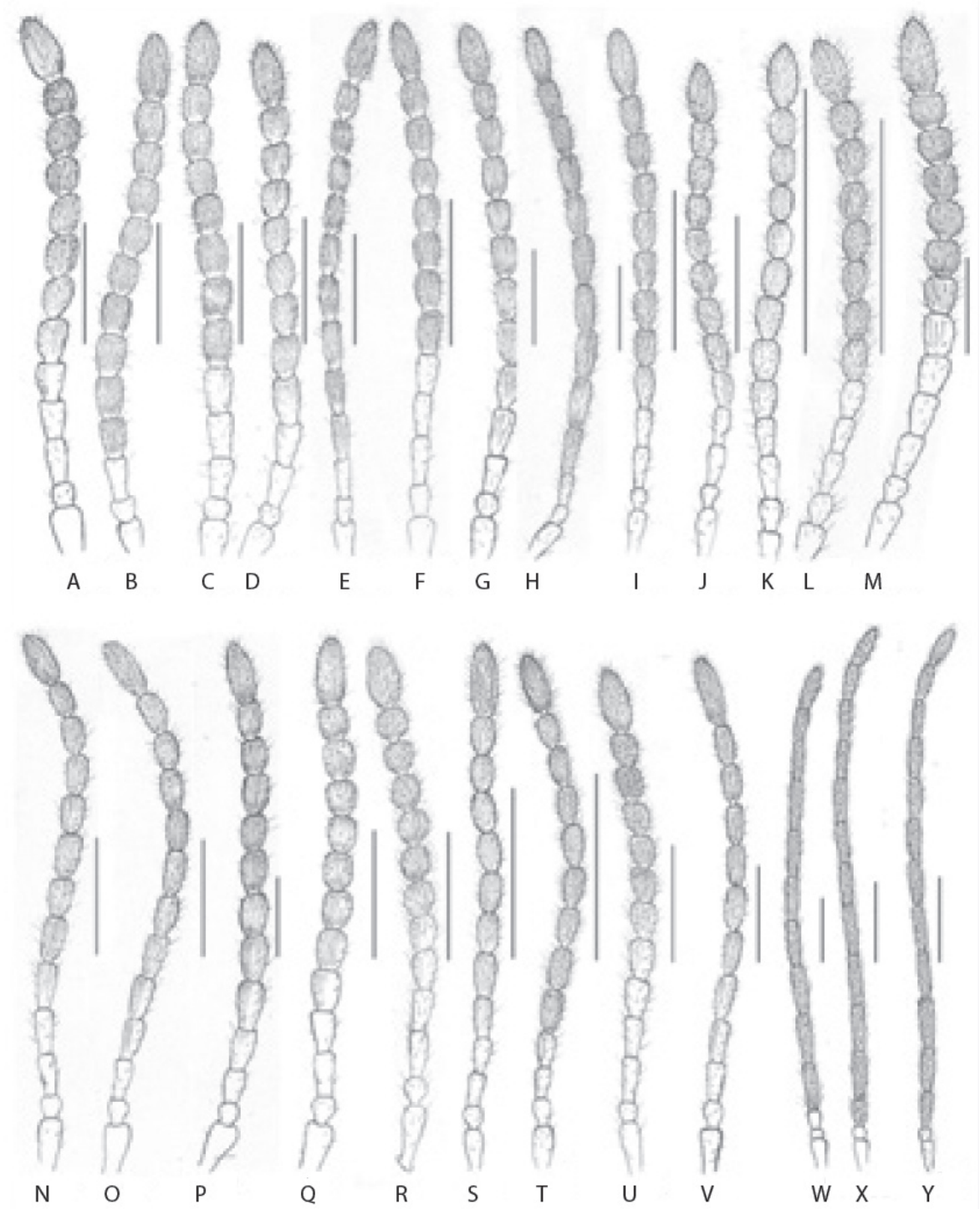

Fig. 11. Antenas de: (A) Neralsia alonsoi n. sp., hembra, (B) N. cressoni n. sp., hembra, (C) N. dettmeri n. sp., hembra, (D) N. julianae n. sp., hembra, (E) N. madrigalensis n. sp., hembra, (F) N. unicarenata n. sp., hembra, (G) N. flavidipennis, hembra, (H) N. hermaphrodita, hembra, (I) N. bogotensis, hembra, (J) N. striaticeps, hembra, (K) N. fossulata, hembra, (L) N. parafossulata, hembra, (M) N. desantisi, hembra, (N) N. francisi, hembra, (O) N. gracielae, hembra, (P) N. magnum, hembra, (Q) N. dianae, hembra, (R) N. claripennis, hembra, (S) N. marioi, hembra, (T) N. rauli, hembra, (U) N. suffecta, hembra, (V) N. vicky, hembra, (W) N. ellongata, hembra, (X) N. ellongata, macho y (Y) N. paraellongata, macho. Escala: $0.5 \mathrm{~mm}$.

Fig. 11. Antennae: (A) Neralsia alonsoi n. sp., female, (B) N. cressoni n. sp., female, (C) N. dettmeri n. sp., female, (D) N. julianae n. sp., female, (E) N. madrigalensis n. sp., female, (F) N. unicarenata n. sp., female, (G) N. flavidipennis, female, (H) N. hermaphrodita, female, (I) N. bogotensis, female, (J) N. striaticeps, female, (K) N. fossulata, female, (L) N. parafossulata, female, (M) N. desantisi, female, (N) N. francisi, female, (O) N. gracielae, female, (P) N. magnum, female, (Q) N. dianae, female, (R) N. claripennis, female, (S) N. marioi, female, (T) N. rauli, female, (U) N. suffecta, female, (V) N. vicky, female, (W) N. ellongata, female, (X) N. ellongata, male y (Y) N. paraellongata, male. Scale: $0.5 \mathrm{~mm}$. 


\section{KEY FOR THE IDENTIFICATION OF THE SOUTH AMERICAN SPECIES}

1. Interfoveal carina of the scutellum, in lateral view, low or hardly surpassing the level of the foveae, without forming

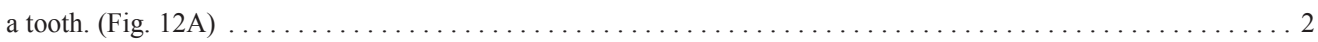

- Interfoveal carina of the scutellum, in lateral view, high, always surpassing the level of the foveae, generally forming

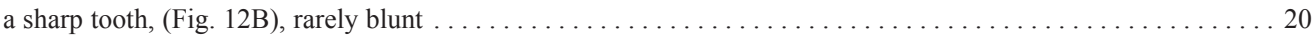

2. Scutellar disc, in lateral view, hunchbacked after the scutellar foveae, with scarcely marked sculpture or smooth (Fig. $1 \mathrm{~A}, \mathrm{~B})$. Females with metasomal tergum II, dense and uniformly striated in the base $(12 \mathrm{H})$. Hairless wings. .N. albipennis (Kieffer)

- Scutellar disc, in lateral view, never hunchbacked; the rest of the characters variable. ............ 3

3. Scutellar spine very short, inconspicuous, reaching at most $1 / 10$ of the total length of the scutellum (Fig. 1D). Scutellar

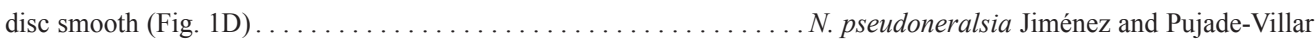

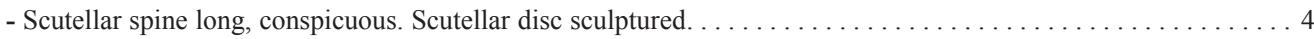

4. Long pubescence, abundant, whitish and woolly in the face, legs and propodeum; disperse in the mesosoma and scarce in the metasoma (Fig. 1E, F). Genal sulcus absent. Male unknown N. pilosa Borgmeier

- Pubescence less abundant and shorter. Genal sulcus more or less marked, with or without internal costulae. . . 5

5. R1 absent or very short (Fig. $10 \mathrm{H}) \ldots \ldots \ldots \ldots \ldots \ldots \ldots \ldots \ldots \ldots \ldots \ldots \ldots \ldots \ldots \ldots$ incompleta Jiménez and Pujade-Villar

- R1 present, reaching or almost reaching the wing margin. $\ldots \ldots \ldots \ldots \ldots \ldots \ldots \ldots \ldots \ldots \ldots \ldots \ldots \ldots$

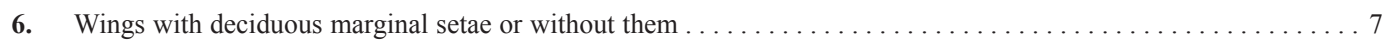

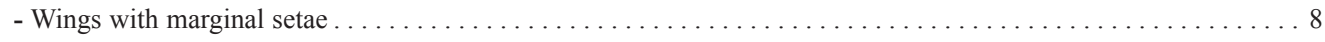

7. Scutelar spine, in dorsal view, very short, in shape of an equilateral triangle; its size is less than $1 / 3$ the total length of the scutellum (Fig. 2B). Central zone of the face smooth . . . . . . . . . . N. equilatera Jiménez and Pujade-Villar - Scutellar spine, in dorsal view, longer, in shape of an isosceles triangle; its size is close to, equal or bigger than $1 / 3$ of the total length of the scutellum (Fig. 2D). Central zone of the face striated.

N. moisesi Jiménez and Pujade-Villar

8. Genal sulcus completely smooth (Fig. 2E). Superior lateral areas of the pronotum smooth or with hardly visible carinae (Fig. 2E). Antennae and legs completely black; metasoma black, ventral part reddish. Female unknown.

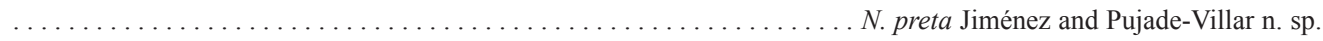

- Genal sulcus with costulae. Superior lateral areas of the pronotum always carinated. Antennae and legs never completely black; metasoma dorsally dark, with a reddish ventral area, more or less extended. . . . . . . . . . 9

9. Scutellar spine, in dorsal view, of uniform thickness in most of its way, often finished in a blunt end (Fig. 2H, 3B, 3D).

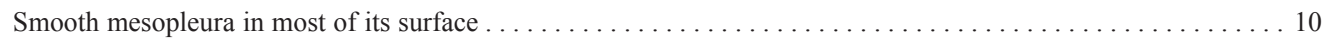

- Scutellar spine, in dorsal view, diminishing its thickness from the base towards the apex, finishing in a sharp end. Mesopleura with numerous thin striae, in the anterior, posterior and ventral part; centre generally smooth . . . . 12 

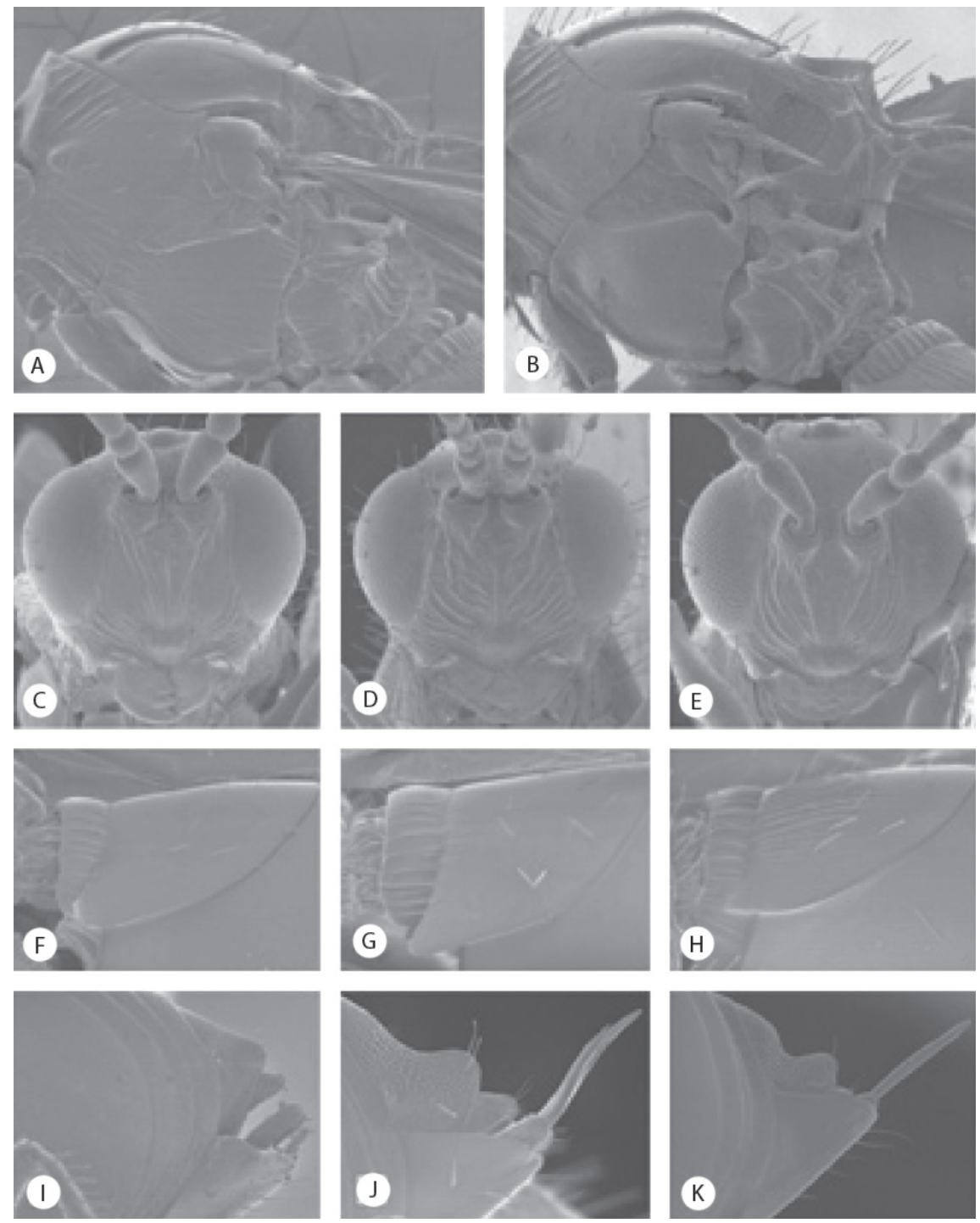

Fig. 12. Caracteres diagnósticos: (A-B) carena interfosal: (A) baja, (B) alta; (C) cara en visión frontal de los machos de Neralsia; (D, E) cara en visión frontal de las hembras de Neralsia: (D) con estrías irradiantes desde el centro, (E) con estrías irradiantes desde el clipeo; (F-H) terguito metasomal II: (F) liso, (G) con escasas carenas en la base, (H) densamente estriado en la base $(\mathrm{H})$; (I-K) terguito metasomal VIII: dorsalmente recto (I), dorsalmente cóncavo $(\mathrm{J})$, dorsalmente inciso (K).

Fig. 12. Diagnostic characters: (A-B) interfoveal carena: (A) low, (B) high; (C) male's faces in frontal view; (D, E) female's faces in frontal view: (d) with striae emanating radially from centre of the face, (E) with striae emanating radially from the clipeo; (F-H) metasomal tergum II: (F) smooth, (G) with scarse striae at base, (H) with numerous striae at base (H); (I-K) metasomal tergum VIII: dorsally straight (I), dorsalmente concave (J), dorsalmente incised (K). 
10. Short scutellar spine, less than $1 / 3$ of the total length of the scutellum (Fig. $2 \mathrm{H}$ ). Genal carina with costulae in all its way (Fig. 2G). Females unknown. . N. difilippoi Jiménez and Pujade-Villar n. sp. - Long scutellar spine, around $1 / 3$ of the total length of the scutellum. Genal carina with costulae only in the inferior third. 11

11. Females with clavated antennae, thick flagellomeres, 1.5 times longer than wide; length of F1 similar to F2 (Fig. 11G). Lateral areas of the pronotum with scarce thick carinae (Fig. 3A). N. flavidipennis (Kieffer) - Females with filiform antennae, thin flagellomeres, most of them 2.5 times longer than wide; length of F1 shorter of F2 (Fig. 11H). Lateral areas of the pronotum with numerous thin carinae (Fig. 3C). Males unknown. N. hermaphrodita Jiménez and Pujade-Villar

12. Metasomal tergum II strongly striated at base (Fig. 12H) . .

- Metasomal tergum II smooth or with short and scarce striae at base (Fig. 12F, G)

13. Scutellar spine shorter than $1 / 3$ of the length of the scutellum (Fig. 3E, F). Females with moniliform flagellomeres (Fig. $11 \mathrm{~K})$. Antennae and legs testaceous. Hyaline wings, venation pale yellow . . . . . . . . . . . fossulata (Kieffer) - Scutellar spine as long as or longer than $1 / 3$ of the length of the scutellum. Female with variable in shape flagellomeres. Antennae of dark or reddish coloration, never testaceous, reddish legs. Wings partially dusky, venationbrown . . . . 14

14. Face of the females with striae that depart from the middle of the face towards the compound eyes and the antennal foveae (Fig. 12D). Mesopleura with longitudinal striae in the inferior half. Females with the last flagellomeres much longer than wide. (Fig. 11I, J). Scutellar spine relatively short, around 1/3 of the total length of the scutellum. . . 15 - Face of the females with striae that depart radially from the clipeus towards the antennal foveae (Fig. 12E). Mesopleura smooth in the middle, with scarce striae in the lateral areas. Females with the last flagellomeres hardly longer than wide (11L). Scutellar spine long, bigger than $1 / 3$ of the total length of the scutellum $\ldots \ldots \ldots \ldots 16$

15. Lateral areas of the pronotum with abundant thin carinae (Fig. 3G). Females with testaceous antennae, the last flagellomeres lighter. N. striaticeps (Kieffer) - Lateral areas of the pronotum with scarce sharp carinae in the dorsal part (Fig. 4A). Females with uniformly dark antennae. .N. bogotensis (Kieffer)

16. Dorsal margin of the metasomal tergum VIII, in lateral view, concave (Fig. 12J). Sinsilia of the flagellomeres scarce and spaced; last flagellomeres ellipsoidal (Fig. 11L). Space between the foveae and the spine of the scutellum, in lateral view, concave (Fig. 4C); spine upwards. Radial cell with Rs very curved (Fig. 10O). Males unknown.

$\ldots \ldots \ldots \ldots \ldots \ldots \ldots \ldots \ldots \ldots \ldots \ldots \ldots \ldots \ldots \ldots \ldots \ldots \ldots \ldots \ldots \ldots \ldots \ldots \ldots \ldots \ldots$. parafossulata Jiménez and Pujade-Villar - Dorsal margin of the metasomal tergum VIII, in lateral view, straight (Fig. 12I). Sensilia of the flagellomeres dense; cylindrical flagellomeres (Fig. 11D). Space between the foveae and the spine of the scutellum, in lateral view (Fig. 4E), straight spine. Radial cell with Rs straight (Fig. 10I). .N. julianae Jiménez and Pujade-Villar n. sp.

17. Medial sulcus of the scutum very marked and long. Lateral areas of the pronotum with scarce thick carinae. Metasomal

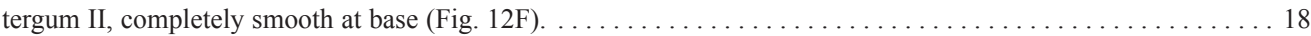
- Medial sulcus of the scutum hardly visible or very short. Lateral areas of the pronotum with abundant thin carinae. Metasomal tergum II, with scarce and short striae at base. (Fig. $12 \mathrm{G}) \ldots \ldots \ldots \ldots \ldots \ldots \ldots \ldots \ldots \ldots \ldots$ 
18. Female antennae with brown-reddish flagellomeres; last flagellomeres sub-squared (Fig. 11M). Scutellar disc with longitudinal carina almost parallel (Fig. 4H). Reddish coxae.. . . . . . . . . . N. desantisi Jiménez and Pujade-Villar - Female antennae with darkish flagellomeres; last flagellomeres cylindrical (Fig. 11B). Scutellar disc with undefined carinae, without delimiting the main sulcus (Fig. 5B). Black coxae. . . . . . cressoni Jiménez and Pujade-Villar n. sp.

19. Scutum with no differentiated medial sulcus (Fig. 5D). Posterior limit of the scutellar foveae absent, indicated only by a change of curvature and/or a change in the sculpture (Fig. 5D); central longitudinal carinae of the scutellar disc weak, delimiting a coriaceous zone (Fig. 5D). Females with facial striae that depart radially from the middle of the face towards the compound eyes and the antennal foveae. (Fig. 12D).. . . . . . . N. rauli Jiménez and Pujade-Villar - Scutum with differentiated medial sulcus (Fig. 5F). Posterior limit of the scutellar foveae represented by a conspicuous carina (Fig. 5F); central longitudinal carinae noticeable, delimiting a smooth zone (Fig. 5F). Females with facial striae that depart radially from the clipeus towards the compound eyes and the foveal antennae. (Fig. 12E).

.N. marioi Jiménez and Pujade-Villar

20. Scutellar spine longer than half the length of the scutellum (Fig. 5G, H). Radial cell longer than wide (Fig. 10E, F). Female antennae with cylindrical flagellomeres, much longer than wide, similar to males (Fig. 11W). Metasomal

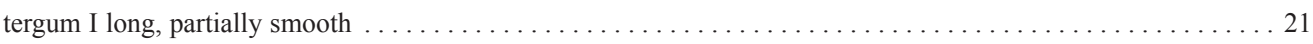
- Scutellar spine shorter than half the length of the scutellum. Radial cell short and wide. Females antennae with flagellomeres variable in shape, never similar to those of males. Metasomal tergum I short, forming a narrow carinated ring . . . .22

21. F1 of the males antennae with a maximum length half of F2 (Fig. 11X). Females with F1 shorter than F2 (Fig. 11W)

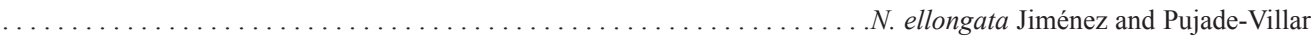
- F1 of the males antennae with a length equal to 3/4 of the length of F2 (Fig. 11Y). Females unknown.

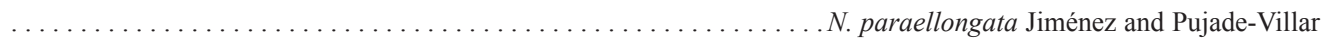

22. Scutellar disc sub-squared (Fig. 6B) (the lateral and posterior margin form a right angle).Scutellar spine short, less than

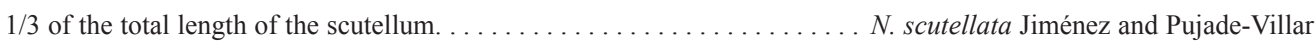
- Scutellar disc never sub-squared (the lateral and posterior margin form no right angle). Scutellar spine longer . . 23

23. Lateral margins of the scutellum elevated, reaching the same height of the interfoveal carina (Fig. 6C). Lateral areas of the pronotum completely smooth in their inferior part (Fig. 6C). Big size (5.1 mm). Males unknown.

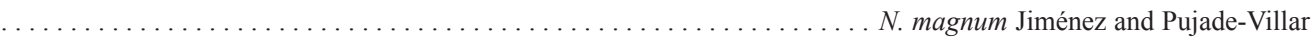

- Lateral margins of the scutellum always below the height of the interfoveal carina Lateral areas of the pronotum

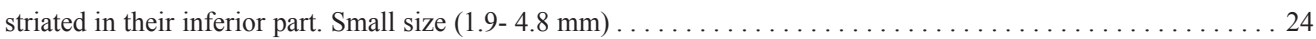

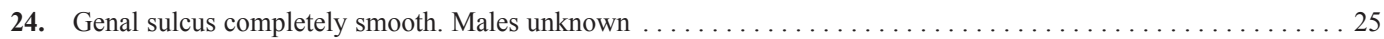

- Genal sulcus with costulae, sometimes scarce or weakly marked. $\ldots \ldots \ldots \ldots \ldots \ldots \ldots \ldots \ldots \ldots \ldots$

25. Lateral areas of the pronotum with sharp, scarce and spaced inferior carinae, (Fig. 6E). Metasomal tergum II with numerous striae at base. Hyaline wings, venation pale yellow, areolet absent (Fig. 10M)

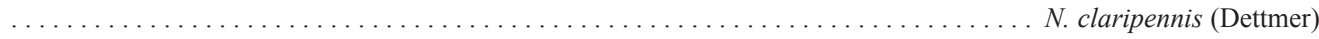

- Lateral areas of the pronotum with fine and dense inferior carinae (Fig. 6G). Metasomal tergum II completely smooth at base. Dusky wings, venation brown, areolet present $($ Fig.10N) . . . . . . . dianae Jiménez and Pujade-Villar 
26. Females with metasomal tergum II striated at base (Fig. 12H); metasomal tergum VIII (in lateral view) strongly incised (Fig. 12K) or with the metasomal tergum II with some spaced striae at base, metasomal tergum VIII (in lateral view)

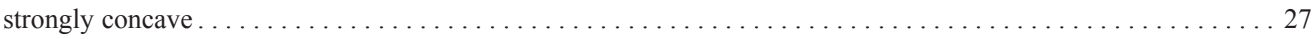

- Females with metasomal tergum II completely smooth at base (Fig. 12F). Metasomal tergum VIII (in lateral view)

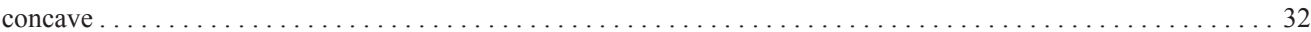

27. Scutellum (in dorsal view) with a single longitudinal carina that begins in the interfoveal carina and finishes in the base

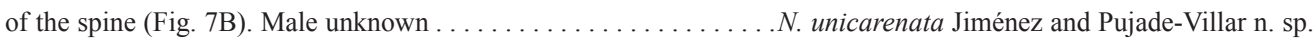
- Scutellum (in dorsal view) with two longitudinal carina that begin in the interfoveal carina or in the posterior part of the foveae, and finish in the base of the spine usually forming a sulcus between them . . . . . . . . . . 28

28. Mesopleura sculptured in most of its surface, central area smooth. Last flagellomeres of the female long, 1.5-1.8 times

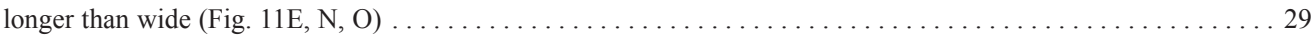
- Mesopleura smooth in most of its surface, ventral area with some weak carina. Last flagellomeres of the female short, 1.2-1.4 times longer than wide.

29. Striae of the face radially departing from the clipeus towards the antennal foveae and inferior part of the compound eyes (Fig. 12E). Male unknown. N. madrigalensis Jiménez and Pujade-Villar n. sp. - Striae of the face radially departing from the middle of the face towards the antennal foveae and inferior part of the compound eyes (Fig. 12D). 30

30. Scutellar spine as long as half the total length of the scutellum; lateral margins of the scutellum uniformly curved before initiating the scutellar spine (Fig. 7F); interfoveal carina in shape of a very sharp tooth (Fig. 7E). Flagellomeres uniformly brown. . . . . f f f ancisi Jiménez and Pujade-Villar - Scutellar spine hardly longer than a third of the total length of the scutellum, lateral margins of the scutellum forming an angle before initiating the scutellar spine (Fig. 7H); interfoveal carina in shape of a blunt tooth (Fig. 7G). Last flagellomeres testaceous. Male unknown. ..................... gracielae Jiménez and Pujade-Villar

31. Disc of the scutellum with abundant longitudinal carina lined up between a strongly marked coriaceous sculpture (Fig. 7B). Genal sulcus weakly costulated (Fig. 8A). Sensilia of the flagellomeres of the females abundant and dense (Fig. 11U).

N. suffecta (Dettmer)

- Disc of the scutellum carinated, without coriaceous sculpture (Fig. 8D). Genal sulcus strongly costulated (Fig. 8C). Sensilia of the flagellomeres of the females scarce and spaced (Fig. 11A)

N. alonsoi Jiménez and Pujade-Villar n. sp.

32. Medial sulcus of the scutum very short (Fig. 8F), hardly marked. Females antennae with F1-F8 of the same length, 1.6 times longer than wide and very thin (Fig. 11V). N. vickyiae Jiménez and Pujade-Villar - Medial sulcus of the scutum long, very marked (Fig. 8H, 9B). Females antennae with shorter flagellomeres and of variable length. 
33. Reddish antennae. Genal sulcus with strongly marked antennae (Fig. 8G). Mesopleura smooth in most o fits surface (Fig. 8G). Interfoveal carina hardly visible, in shape of a blunt tooth (Fig. 8G)

N. obelix Jiménez and Pujade-Villar

- Dark brown antennae. Genal sulcus with costulae weakly marked (Fig. 9A). Mesopleura dense and slightly striated in the ventral part (Fig. 9A). Interfoveal carina visible, in shape of a sharp tooth (Fig. 9A).

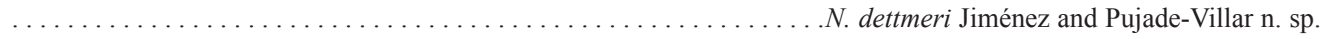

In brief and as a result of the presented taxonomical survey:

Twenty six species of the genus Neralsia present in South America have been comparatively studied.

Observations of systematical characters were made, important at the time of identification, to $N$. claripennis, $N$. ellongata, $N$. hermaphrodita, $N$. obelix and $N$. paraellongata.

We revised additional material of $N$. albipennis, N. bogotensis, $N$. desantisi, N. ellongata, N. francisi, $N$. gracielae, N. marioi, $N$. obelix, N. pseudoneralsia, $N$. rauli, N. striaticeps, $N$. suffecta and $N$. vickyae; for some of these species, the aforementioned material allow increasing the knowledge of their geographical distribution, such as in the case of $N$. desantisi, $N$. gracielae, $N$. obelix N. pseudoneralsia, $N$. striaticeps and $N$. vickyae.

Eight new species were described, and with them the number of Neralsia species in this part of the continent is increased to 34 and a key was developed to allow their identification.

\section{ACKNOWLEDGMENTS}

We thank all the previously mentioned institutions and their respective responsible people for sending the material to be studied. We thank the Universidad de Barcelona, España, Universidad Nacional de La Plata and Consejo Nacional de Investigaciones Científicas y Técnicas, Argentina for their constant support, and Cecilia Gorreta for the technical support.

\section{RESUMEN}

Neralsia es un género de himenópteros de distribución americana, presente tanto en la región Neártica como en la Neotropical. En este trabajo se estudian, usando microscopia de luz y electrónica, las especies sudamericanas en su conjunto, 26 anteriormente citadas y ocho especies nuevas, que se describen aquí formalmente. Se presenta, además, una clave para su identificación; y se ilustran los caracteres que permiten definir las especies consideradas en este estudio.

Palabras clave: Cynipoidea, Figitidae, Figitinae, Neralsia, Sudamérica, revisión, nuevas especies.

\section{REFERENCES}

Ashmead, W.H. 1887. On the Cynipidous galls of Florida, with descriptions of new pecies and synopsis of described species of North America. Trans. Am. Ent. Soc. 14: 125-158.

Ashmead, W.H. 1896. Descriptions of new parasitic Hymenoptera. Trans. Am. Ent. Soc. 23:179-234.

Borgmeier, T. 1935. Sobre alguns Cynipideos parasiticos e Cecidogenos do Brasil (Hymenoptera, Cynipidae). Arch. Inst. Biol. Veget. Río de Janeiro 2: 97-124.

Cameron, P. 1883. Fam. Figitidae. In F.D. Godman \& O. Salvin (eds.). Biologia Centrali-Americana or Contributions to the knowledge of the fauna and flora of Mexico and Central America, vol. I (Hymenoptera). Taylor and Francis, London.

Clavijo, S. 1993. Fundamentos de manejo de plagas. Univer. Central Venez. Consejo desarrollo Cient. Humanístico, Caracas, Venezuela.

Dettmer, H. 1932. Beschreibung einiger südamerikanischer Arten der Gattung Xyalophora Kieffer. Brotéria, ser. Cienc. Nat. 1: 120-143. 
Díaz, N.B. 1990. Presencia de Neralsia splendens en la República Argentina (Cyn. Figitidae). Neotrópica 36: 22.

Díaz, N.B. \& F.E. Gallardo. 1995. Nuevos aportes al conocimiento de Neralsia splendens en la Rca. Argentina. (Hym., Cyn., Figitidae). Rev. Soc. Entomol Argent. 54: 74 .

Díaz, N.B. \& F.E. Gallardo. 1996. Sobre Cinipoideos de Brasil, parasitoides de dípteros estercoleros (Hymenoptera: Cynipoidea). Rev. Soc. Entomol. Argent. 55: 127-129.

Díaz, N.B., F.E. Gallardo, C. Marchiori \& A. Linhares. 2000. Cynipoidea parasitoids of dung-flies in Brazil. II (Insecta: Hymenoptera). An. Soc. Entomol. Brasil. 29: 469- 474 .

Gibson, G.A.P. 1985. Some pro- and mesothoracic characters important for phylogenetic analysis of Hymenoptera, with a review of terms used for structures. Can. Entom. 117: 1395-1443.

Giraud, J. 1860. Enumeration des Figitides de l'Autriche. Ver. Zool.-Bot. Ges. Wien. 10: 123-176.

Harris, R.A. 1979. A glossary of surface sculpturing. Occ. Pap. Ent. Calif. 28: 1-31.

Jiménez, M., N.B. Díaz, F.E. Gallardo, P. Ros-Farré \& J. Pujade-Villar. 2004. Las especies sudamericanas del género Neralsia Cameron (Hymenoptera: Cynipoidea: Figitidae: Figitinae): estudio del material tipo. Butll. Inst. Cat. Hist- Nat. 72: 61-81.

Jiménez, M., N.B. Díaz, F.E. Gallardo, P. Ros-Farré \& J. Pujade-Villar. 2005a. Resultados preliminares del estudio de las especies sudamericanas del género Neralsia Cameron (Hymenoptera: Cynipoidea: Figitidae: Figitinae). Ses. Entom. ICHN-SCL 13: 73-84.

Jiménez, M., N.B. Díaz, F.E. Gallardo, P. Ros-Farré \& J. Pujade-Villar. 2005b. Descripción de ocho especies sudamericanas del género Neralsia Cameron 1883, con carena escutelar alta (Hymenoptera, Cynipoidea, Figitidae). Nouv. Revue Ent. (N.S.). 22: 165-179.

Jiménez, M., N.B. Díaz, F.E. Gallardo, P. Ros-Farré \& J. Pujade-Villar. 2006a. Descripción de nueve especies sudamericanas del género Neralsia Cameron, con carena escutelar baja (Hymenoptera: Cynipoidea: Figitidae). Neotrop. Entomol. 31: 59-69.

Kieffer, J.J. 1901. Notes sur les Cynipides (Hymén.). Bull Soc. Ent. France. 1: 343-344.
Kieffer, J.J. 1909. Description de nouveaux Cynipides zoophages (2ème partie). Bull. Soc. Hist. Nat. Metz. 26: 57-96.

Madrigal-Cardeño, A. 2001. Fundamentos de Control Biológico de Plagas. Universidad Nacional de Colombia, Medellín, Colombia.

Marchiori, C., A. Oliveira, N.B. Díaz, F.E. Gallardo, M. Penteado-Dias \& A. Linhares. 2000a. Cynipoidea (Hymenoptera) associados com fezes bovinas e colectados em areas de mata nativa e pastos em Goias. Arq. Inst. Biol., São Paulo 67: 19-23.

Marchiori, C. 2000b. Parasitóides de estágios imaturos de dípteros sinantrópicos colectados em vários ambientes em Itumbiara-GO. Acta Scienctiarum 22: $655-661$

Marchiori, C., C. Vieira, E. Caldas, F. Teixeira, C. Silva \& A Linhares. 2000c. Dipteros muscóides asociados com fezes bovinas e seus parasitóides em Giás. Arq. Bras. Med. Vet. Zootec. 52: 354-356.

Marchiori, C., A. Lindares \& M. Penteado-Dias. 2000d. Occorréncia de Figitidae (Hymenoptera: Cynipoidea) em Itumbiara, Goiás, Brasil. Pesq. Agrop. Trop. 30: 69-71.

Marchiori, C., A. Oliveira, M. Penteado-Dias, D. Scatolini, N.B. Díaz \& F.E. Gallardo. 2000e. Fauna de Parasitóides asociados a Diptera Cyclorrhapha (Insecta). Arq. Inst. Biol. São Paulo. 67: 195-198.

Marchiori, C., A. Oliveira, E. Rodrigues \& A. Craças. 2003. Parasitoids collected from artificial bovine dung pats exponed for different periods of time in Itumbra, Goiás, Brazil. Acta Scientiarum: Biological Sciencies, Maringá 1: 9-13.

Pujade-Villar, J., J. Paretas-Martínez \& M. Jiménez. 2006. Description of a new species of Neralsia Cameron with a wide distribution in the American continent: $N$. incompleta n. sp. (Hymenoptera: Figitidae: Figitinae). Ann. Soc. entomol. Fr. (n.s.). 42: 45-49.

Ronquist, F. \& G. Nordlander. 1989. Skeletal morphology of an archaic cynipoid, Ibalia rufipes (Hymenoptera, Ibaliidae). Ent. scand., Suppl. 33: 1-60.

Weld, L.H. 1930. Notes on types (Hymenoptera, Cynipidae). Proc. Ent. Soc. Wash. 32: 137-144.

Weld, L.H. 1952. Cynipoidea (Hymenoptera) 1905-1950. Privately printed, Ann. Arbor, Michigan, EEUU. 